\title{
A dialética do método da economia política na introdução aos Grundrisse *
}

\author{
Cláudio Gontijo **
}

\section{Resumo}

Este artigo procura examinar, ainda que de forma sintética, a Introdução aos Grundrisse, cotejando-a não apenas com outros textos de Marx, mas também com Hegel, de forma a esclarecer alguns dos aspectos essenciais da dialética marxista. Em particular, discute-se a dicotomia método de pesquisa $\mathrm{x}$ método de exposição; a differentia specifica da dialética hegeliano-marxista em relação à lógica aristotélica; a questão da forma e conteúdo; as relações entre entendimento e razão dialética e entre o silogismo formal e o silogismo dialético; a crítica marxista do idealismo hegeliano; as razões pelas quais "a anatomia do homem é a chave da anatomia do macaco"; assim como as limitações da Introdução aos Grundrisse, em face de outras dimensões da dialética marxista.

Palavras-chave: Método marxista; Dialética materialista; Marx e Hegel; Materialismo histórico; Introdução aos Grundrisse.

\begin{abstract}
This article examines, albeit in a synthetic fashion, the Introduction to the Grundrisse, comparing it not only to other texts written by Marx, but also to Hegel, in order to clarify some essential aspects of Marxist dialectics. In particular, it discusses the dichotomy method of inquiry x method of exposition; the differentia specifica of Marxian Hegelian dialectic in relation to Aristotelian logic; the question of form and content; the relationship between understanding and dialectic reason and between formal syllogism and dialectic syllogism; the Marxian critique of Hegelian idealism; the reasons why "the anatomy of man is the key to the anatomy of the ape"; as well as the limitations of the Introduction to the Grundrisse in the face of other dimensions of Marxist dialectics.
\end{abstract}

Keywords: Marxian method; Materialistic dialectics; Marx and Hegel; Historical materialism; Introduction to the Grundrisse.

JEL B14, B41, B51.

\section{Introdução}

Embora a Introdução aos Grundrisse (IG, Marx, 1857, p. 116-125) seja citada com frequência, De Paula (2010, p. 89) parece correto ao afirmar que "[n]ão são muitas as tentativas de leitura circunstanciada, passo a passo, e compreensiva" do mesmo, destacando-se, entre as poucas exceções, além do seu próprio texto, o trabalho de Miriam Limoeiro (1977), o Prefácio e o Capítulo I do livro de Hiroshi Uchida (1988) e o Capítulo 5 do livro de Jesus Ranieri (2011). Esta escassez de

* Artigo recebido em 8 de fevereiro de 2014 e aprovado em 8 de janeiro de 2016.

${ }^{* *}$ Professor Associado do Departamento de Ciências Econômicas da Universidade Federal de Minas Gerais (UFMG). E-mail: gontijo@face.ufmg.br. 
comentários, por si só, justificaria o presente artigo, que procura discutir, ainda que de forma sintética, a IG, cotejando-a não apenas com outros textos de Marx, mas também com Hegel, de forma a esclarecer alguns dos aspectos essenciais da dialética marxista. Todavia, mais do que isto, ele procura superar algumas das aparentes deficiências dos textos assinalados, a começar pelo de Limoeiro, que faz uma leitura althuseriana da IG, centrada na separação formalista entre o conceito e o real, de difícil sustentação. Quanto ao artigo de De Paula, apesar de enriquecedor do ponto de vista da discussão das relações entre a IG e os economistas burgueses anteriores e contemporâneos de Marx, faz poucas referências à tradição filosófica, inclusive hegeliana, que subjaz ao texto marxista. Já os textos de Uchida apresentam muitos problemas, a começar pela correspondência que estabelece entre a IG e a doutrina hegeliana do Conceito; o julgamento que faz da Lógica de Hegel a partir dos Manuscritos Econômicos e Filosóficos, obra da juventude de Marx, que, conforme demonstra Giannotti (1966), ainda não supera o idealismo; a comparação externa entre a perspectiva marxista e a de Smith e Ricardo; a contraposição que faz entre o "método analítico" de Hegel e o caminho da pesquisa de Marx; entre outros. Finalmente, o trabalho de Raniere, além de abordar apenas parte da IG, embora de forma sugestiva, apresenta certa ambiguidade no que diz respeito à relação entre o universal, o particular e o singular, ao significado do concreto e da abstração, assim como da relação entre a realidade do capital e o seu conceito. Apear de ser de grande interesse a discussão pormenorizada desses textos, a mesma faria com que o presente ensaio ultrapassasse, em muito, os seus limites, de modo que será deixada para outra oportunidade.

Este artigo desdobra-se em oito seções, além da presente Introdução. Na seção 1 discute-se a differentia specifica da dialética hegeliano-marxista em relação à lógica aristotélica, questão que surge no início da seção sobre o método da economia política, seguindo-se, na seção 2, a discussão sobre forma e conteúdo que a sucede. Já a seção seguinte aborda as relações entre entendimento e razão dialética, esclarecedora da Parte 2 da IG, enquanto que a questão do silogismo formal, que também aparece na Parte 1 e Parte 2 (p. 108), é discutida na seção 4. Na seção 5 discute-se a dicotomia método de pesquisa $\mathrm{x}$ método de exposição, levantada por Marx logo no início da Parte 2 da IG, referente ao método, enquanto a crítica marxista do idealismo hegeliano, tratado na Parte 3, é abordada na seção 6. A seção seguinte discute por que "a anatomia do homem é a chave da anatomia do macaco" (IG, p. 120-122), enquanto que a seção final apresenta as limitações da IG, em face de outras dimensões da dialética marxista que não foram nela endereçadas.

\section{Do geral abstrato ao universal concreto}

Marx (IG, p. 116) inicia o seu texto O Método da Economia Política perquirindo sobre qual deve ser o começo dessa ciência. Fornecendo uma resposta 
que, à primeira vista, parece emanar da sua perspectiva materialista, afirma que "[p]arece que o correto é começar pelo real e pelo concreto, que são a pressuposição prévia e efetiva; assim, em Economia, por exemplo, começar-se-ia pela população, que é a base e o sujeito do ato social de produção como um todo". Todavia, apesar dessas fortes razões para se iniciar pela população, Marx (IG, p. 116) a rejeita, ponderando que

graças a uma abstração mais atenta, tomamos conhecimento de que isto é falso. A população é abstração, se desprezarmos, por exemplo, as classes que a compõem. Por seu lado, estas classes são uma palavra vazia de sentido se ignorarmos os elementos em que repousam, por exemplo: o trabalho assalariado, o capital, etc. O capital, por exemplo, sem o trabalho assalariado, sem o valor, sem o dinheiro, sem o preço, etc., não é nada.

É claro que, à primeira vista, essas assertivas parecem subverter inteiramente o sentido dos conceitos de real e concreto, assim como contradizer o próprio materialismo marxista, pois a população é definitivamente algo concreto, real e imediato, podendo, desde que se utilize a técnica estatística adequada, até ser mensurada, inclusive em sua estratificação por classes sociais. Todavia, o mistério se resolve quando se considera os significados das categorias concreto e abstrato de uma perspectiva dialética, em oposição à perspectiva da lógica formal, de origem aristotélica.

Nos Segundos Analíticos (II, XII, 96b e 97b, 6-14), Aristóteles (384 a.C.322 a.C.) afirma que o conceito representa o abstrato, ou universal abstrato, predicado de muitos, o geral que se forma a partir da abstração do que há de diferente, seja nos indivíduos singulares, existentes, ou em conceitos particulares.

A partir dessa concepção, pode-se construir, como demonstrou Porfírio de Tiro (233-304), comentador de Aristóteles, uma hierarquia de conceitos denominada árvore porfiriana (Figura 1) -, obtidos por meio de abstrações sucessivas, que caminham das espécies ínfimas (infimae species) - aquela que não admite subespécies - para espécies mais gerais, gêneros, até se chegar ao gênero supremo. Assim, considerando-se o que há de comum entre os indivíduos humanos, obtém-se o conceito de homem, ou espécie humana; abstraindo-se, então, das diferenças específicas entre os homens e os outros animais, obtém-se o gênero imediatamente acima, o animal. O gênero imediatamente subsequente é o de ser vivente e, mais abstrato do que ele, está o conceito de ser corpóreo, acima do qual está, segundo Aristóteles, a substância, que seria o gênero supremo, acima do qual não haveria qualquer outro. 
Figura 1

A árvore Porfiriana

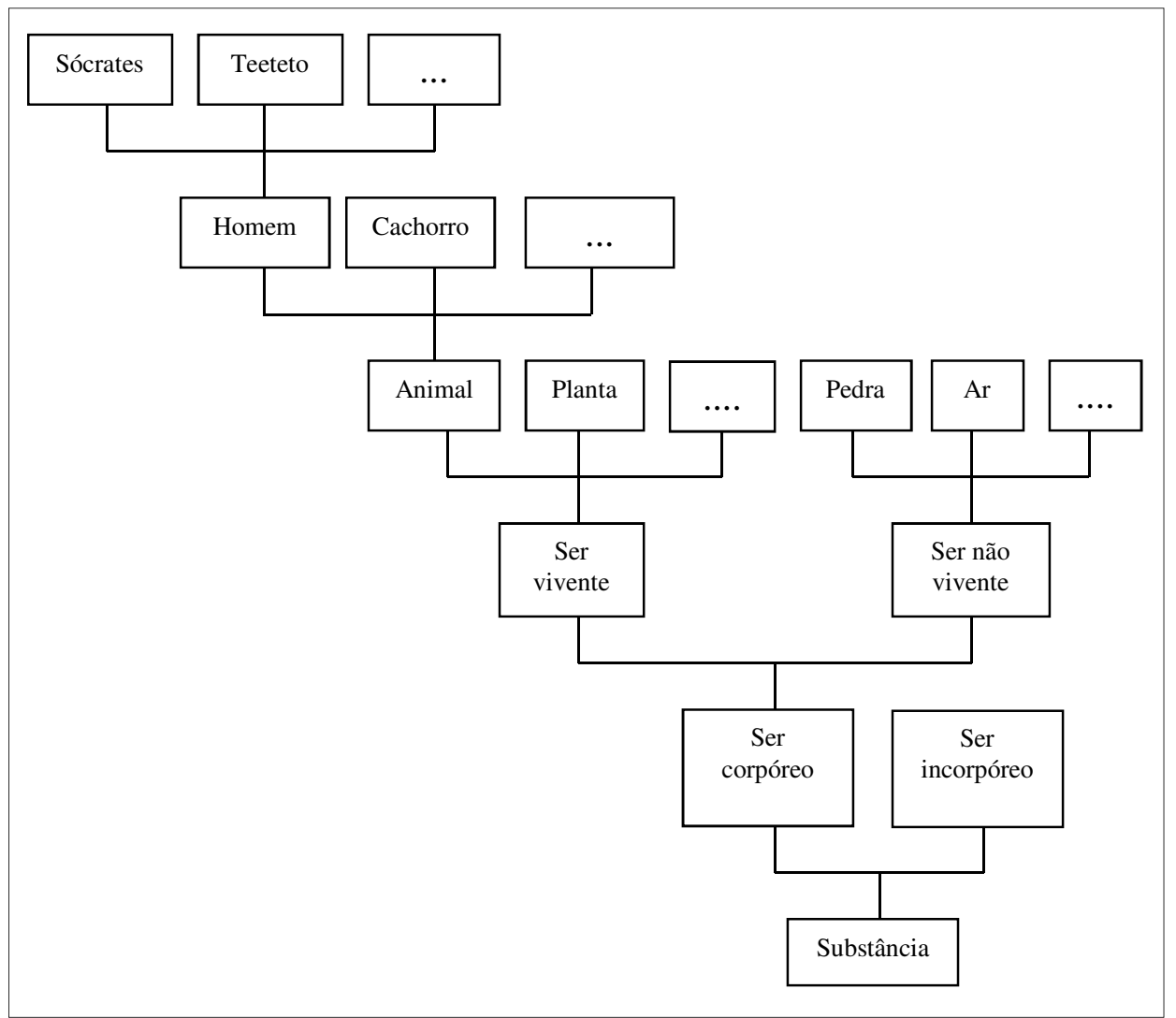

Segue-se que, conforme assinala Ilyenkov (1960, Cap. 1, p. 13) "[q]uanto mais características/determinações são adicionadas a um conceito", ou seja, mais longe da base e perto do topo da árvore porfiriana, "mais concreto ele se torna (...), ou seja, mais definido, mais rico em determinações". Como consequência, "[a]través do uso [mais] abstrato, um conceito aproxima-se de um gênero mais elevado; através de um uso [mais] concreto, ele se aproxima do indivíduo" (idem), de forma que, "[a]través de conceitos muito abstratos, aprendemos pouco sobre muitas coisas; através de conceitos muito concretos, aprendemos muito sobre poucas coisas" (Kant, Lógica, apud Ilyenkov, ibidem).

Nessa formulação, o conceito teria atravessado a história (Ilyenkov, 1960, cap. 1), tendo presidido a controvérsia entre o realismo e o nominalismo na Idade Média, a oposição entre a carne e o espírito da Igreja medieval e mesmo a contraposição entre o empirismo e o racionalismo do período moderno, passando pelo criticismo kantiano e pelo positivismo, para desembocar no pensamento filosófico contemporâneo. 
No entanto, em que pese essa tradição, esta lógica abstrata, que caminha de níveis mais concretos para níveis mais gerais e abstratos por eliminação de determinações particulares ou, inversamente, de níveis mais elevados de abstração para níveis mais concretos, por meio da adição de diferenças específicas, descendo ou escalando a árvore porfiriana, difere radicalmente da lógica marxista hegeliana, de natureza concreta. O motivo é que, conforme esclarece Hegel (1812, p. 99), "[a] existência significa um ser determinado", e, como toda determinação é uma particularidade, a supressão do particular para constituir o geral elimina o caráter concreto da categoria assim constituída, ou seja, aquilo que efetivamente garante sua realidade.

Com efeito, ao examinar a categoria mais geral e abstrata de todas - o conceito de ser em geral -, que abrange tanto a substância quanto a não substância, permitindo, pois, completar a árvore porfiriana, Hegel $(1812$, p. 77) afirma que, em sua imediaticidade, esse ser

é igual somente a si mesmo e tampouco é desigual frente a outro; não tem nenhuma diferença (...). É a pura indeterminação e o puro vazio. Não há nada nele que se possa intuir (...). Tampouco há nada nele que se possa pensar, ou melhor, este é igualmente um pensar vazio. O ser, o imediato indeterminado, é na realidade o nada, nada mais nem nada menos que o nada.

Aliás, isto era reconhecido pelo próprio Aristóteles (Analíticos Primeiros, 91b, 10), que afirma que "o ser não é a entidade de nada: pois o que é não é um gênero" (vide, ainda, Mure, 1950, p. 33). Também Kant (1787, p. 175) o reconhece, quando afirma que "o objeto de um conceito para o qual não se pode obter absolutamente nenhuma intuição correspondente [ - como o ser em geral -$]$ é = nada, isto é, um conceito sem objeto"

Apesar da argumentação de Hegel deixar claro que o geral é uma abstração sem existência concreta, pois não há nada nele, o mesmo ocorre com as categorias da lógica formal criada por Aristóteles, pois são construídas a partir do que há de geral, ou seja, de comum, nos seres que a compõem. O mesmo ocorre, como se viu acima, com as categorias de Kant, já que, conforme esclarece Cunningham (1910, p. 12),

[o]s pensamentos, de acordo com Kant, ainda que categorias universais e necessárias, são apenas nossos pensamentos - separados das coisas por um abismo intransponível, na medida que essas existem à parte de nosso conhecimento. Em outras palavras, as categorias de Kant podem, de fato, informar-nos sobre as relações temporais e espaciais dos objetos, mas exatamente por essa razão não nos podem fornecer nenhum insight sobre a natureza última da realidade.

(1) Não obstante, Kant não percebeu que um conceito sem objeto é o conceito vazio e, portanto, é diferente do nada. 
Como exemplo, tome-se o conceito aristotélico de substância, que abrange os seres corpóreos e incorpóreos. Ora, assim como o incorpóreo, o ser corpóreo não existe enquanto tal, mas é um produto da abstração da mente, que procura o que há de comum. Em outras palavras, o geral e, por via de consequência, todas as categorias da lógica formal são abstrações sem existência concreta nem realidade efetiva; são "vazios de sentido"; "não são nada", como aponta Marx. Trata-se, assim, meramente, de "uma noção abstratamente geral ou representação (Vorstellung), uma forma de conhecimento empírico, de um estágio sensual da consciência" (Ilyenkov, 1960, Cap. 1, p. 14). ${ }^{2}$ Aliás, o próprio Aristóteles reconhecia que o conceito geral, não existe, pois apenas indivíduos singulares ou coisas singulares têm existência concreta. Desse modo, as categorias gerais, ou seja, os universais, seriam apenas qualidades comuns dos indivíduos e das coisas individuais. A mesma perspectiva encontra-se também em Kant (1787, apud Lukács, 1922, p. 143), para quem “[o] ser não é manifestamente um predicado real, isto é, o conceito de qualquer coisa que se possa juntar ao conceito de uma coisa".

Em contraposição, conforme aponta Hegel (1812, p. 99), se a existência significa um ser determinado, "sua determinação é uma determinação existente, uma qualidade" e "[p]or meio de sua qualidade, algo está frente a algum outro, é mutável e finito, determinado". E por ser a existência "um ser determinado, um ser concreto", nele "se abrem em seguida múltiplas determinações, diferentes relações de seus momentos" (idem, p. 100), de modo que, como assegura Marx (IG, p. 116), "o concreto é concreto porque é a síntese de múltiplas determinações; portanto, unidade do diverso".

Não é por outro motivo que Marx nega "a existência da produção em geral, pela afirmação de que toda produção é historicamente condicionada" (De Paula, 2010, p. 95):

Quando se trata, pois, de produção, trata-se da produção em um grau determinado do desenvolvimento social, da produção dos indivíduos sociais. Por isso, poderia parecer que, ao falar da produção em geral, seria preciso que seguir o processo de desenvolvimento e suas diferentes fases, quer declarar que o primeiro momento que se trata de uma determinada época histórica, da produção burguesa moderna, por exemplo (...). Mas todas as épocas da produção têm certas características comuns, certas determinações comuns. A produção em geral é uma abstração, mas uma abstração que tem um sentido, ${ }^{3}$ na medida em que, efetivamente sublinhando e precisando os traços comuns, poupa-nos a repetição (Marx, IG, p. 104)

(2) Grifo nosso. Vorstellung significa, literalmente, o que se está diante de. Para Hegel, representa a primeira elaboração da percepção do objeto (intuição), mas ainda sem ser processada de forma lógica, por meio de conceitos.

(3) Na tradução de Giannotti e Edgar Malagodi, consta "abstração razoável", o que parece inadequado. Preferiu-se, pois, a tradução para o espanhol de José Arico, Miguel Murmis e Pedro Scarón, conforme a edição dos Grundrisse de 1971 da Siglo Vientiuno. 
Em outras palavras, embora o conceito de produção em geral seja útil, na medida em que nos poupa a repetição, trata-se de uma abstração, de algo que não existe, pois, "quando se trata (...) de produção, trata-se [sempre] de produção em um grau determinado do desenvolvimento social", da produção socialmente determinada, dependente, portanto, do modo de produção. Pela mesma razão, sem considerar as suas determinações - as classes sociais -, "a população é abstração", da mesma forma que as classes sociais "são uma palavra vazia de sentido se ignorarmos os elementos em que repousam".

\section{Forma versus Conteúdo}

Mas “[s]e não existe uma produção em geral” (Marx, IG, p. 105), tampouco a produção é apenas uma produção particular; antes, "toda produção é apropriação da natureza pelo indivíduo, no interior e por meio de determinada forma da sociedade" (idem, p. 106). ${ }^{4}$ Em outras palavras, o que existe não é a produção em geral, que é uma abstração vazia, mas um modo de produção, uma forma social concreta de produção. Assim como o socialismo primitivo, o escravismo e o capitalismo, também o capitalismo é uma forma concreta de existência da sociedade, um modo particular de produzir. Logicamente, isso significa que, ao contrário do que sustenta a lógica formal, que "abstrai de todo conteúdo do conhecimento (seja puro ou empírico) e se ocupa apenas com a forma do pensamento" (Kant, 1787, p. 101), de modo que é fixa e independente do conteúdo, que, dado de fora, a preenche a partir da experiência, é a forma que determina o conteúdo concreto, a essência existente. Nessa concepção, Marx segue novamente a Platão, para quem a forma é a ideia que, como no caso de um ovo de um pato, em que "há um princípio de ordem que faz com que daquele ovo se desenvolvam sempre patos", "a forma determina o que a coisa é e com ela vai desenvolver-se" (Cirne Lima, 1997a, p. 44).

Uma vez mais, a mesma concepção se encontra em Hegel (1812, p. 395), segundo o qual "[a] essência tem uma forma e determinações de tal forma", de modo que a forma "é o que põe e determina" (idem, p. 396). Não obstante, "na ciência, o conteúdo encontra-se essencialmente ligado à forma" (Hegel, 1820, p. 3), ou melhor, "o conteúdo (...) tem uma forma e uma matéria que lhe pertencem e lhe são essenciais; ele constitui a unidade de ambas" (idem, 1812, p. 401). Em vez, portanto, de estar separada do conteúdo, determinando a matéria do exterior, como quer a lógica aristotélica, "o que se considera, numa primeira reflexão ordinária, como conteúdo, separado da forma, na realidade não pode estar sem forma, indeterminado em si (...), senão que, pelo contrário, tem uma forma em si mesmo, e que somente através dessa tem animação e conteúdo" (ibidem, p. 37).

(4) Como afirmam Marx e Engels (1845-46, p. 19), o que os indivíduos são coincide "com sua produção, tanto com o que produzem como o modo como produzem".

Economia e Sociedade, Campinas, v. 25, n. 1 (56), p. 209-246, abr. 2016. 
Isto permite, portanto, identificar a forma do método das ciências da natureza e do homem, que, conforme demonstra Hegel na Ciência da Lógica, segue o desdobrar-se da razão dialética, constituindo um discurso lógico (logos), cujo conteúdo é o do próprio pensamento racional, "em seu desenvolvimento necessário" (Hegel, 1812, p. 31). Ao examinar a linguagem, no Prefácio à Segunda Edição, Hegel mostra como, nessa démarche, se vão revelar as determinações do pensamento - as categorias -, estabelecendo a identidade e a diferença no interior do próprio pensamento. Para exemplificar, Hegel toma a categoria mais abstrata e geral do pensamento, que encerra, como gérmen, "todo o desenvolvimento" ulterior do pensamento racional: o ser. Conforme visto na seção 1, o ser indeterminado está, paradoxalmente, determinado pelo nada, ou seja, tem o nada como seu conteúdo. A solução desta "contradição", ou seja, dessa identidade entre o ser e o nada, encontrase no vir a ser (devir), em que ambos, o ser e o nada, estão presentes: o nada somente se torna ser e o ser se torna nada em razão dessa identidade fundamental entre ambos 5 .

Por outro lado, o vir a ser, o nascer e o perecer, como já haviam considerado os filósofos gregos, são determinações da realidade existente, dos seres concretos, que, como tais, são dados da experiência sensível. Assim, se é a forma lógica que permite ao pensamento conceber a realidade sensível (conteúdo ou matéria), que por ele é penetrada, esta forma não é a do sujeito, que a impõe à realidade, como no pensamento formal, particularmente em Kant, mas da própria realidade. Por via de consequência, há coincidência entre a forma do pensamento que concebe e a forma do ser da realidade concreta.

Finalmente, registre-se que esta forma determinada do ser, ou seja, o ser determinado, é o produto do conteúdo do ser em geral (o nada), sem o qual seria o ser em geral, indeterminado. O conteúdo, portanto, é que determina a forma, de modo que há uma dupla relação entre forma e conteúdo. Se é a forma que determina o ser, de modo que o ser determinado é uma forma de ser e, portanto, o seu conteúdo, essa forma, por sua vez, nasce do próprio movimento do conteúdo do ser, que se desdobra em uma forma de ser. O conteúdo, assim, determina a forma que, por sua vez, determina o conteúdo, de modo que ambas se determinam mutuamente ${ }^{6}$.

Não se pode definir a dialética, portanto, como método que se aplica a todo o conteúdo, ou seja, sem conteúdo, visto que "no conhecimento dialético, não se tem preparadas formas lógicas que são aplicadas indiferentemente a qualquer conteúdo, uma vez que o conhecimento do conteúdo depende dessas formas" (Vaz, 1982, p. 15). A dialética, portanto, é a lógica do conteúdo, que lhe dá forma, que, por sua

(5) O devir é o pensamento sustentando e animando nossa experiência do ciclo sem fim do tornar-se e perecer de todas as coisas perceptíveis no mundo espaço temporal (Mure, 1950, p. 36).

(6) Nesse sentido, "o conteúdo, no sentido dialético, são as coisas tais como são pensadas na sua complexidade, através das oposições que essa complexidade manifesta” (Vaz, 1982, v. 4, p. 25). 
vez, o determina, de modo que "[o] método dialético só pode ser entendido se o descobrirmos num conteúdo no qual ele já esteja presente o estruturando de forma imanente" (idem, p. 29). Assim, "é o próprio conteúdo que explicita a sua logicidade interna" (idem).

Sumarizando, nas palavras de Kojève (1947, p. 422), “o pensamento lógico que se supõe verdadeiro, o conceito que se supõe adequado apenas revela ou descreve o Ser tal como ele é ou tal como ele existe, sem nada retirar, sem modificálo em nada. A estrutura do pensamento é, portanto, determinada pela estrutura do Ser que ela revela". Nesse sentido, "[o] conhecimento científico se faz ou se entrega sem reservas, sem ideias pré-concebidas nem segundas intenções à vida e ao movimento dialético do real" (idem, p. 424); "é o próprio real que se revela pelo conhecimento que fala e que, assim, se torna objeto conhecido que tem como complemento necessário o sujeito cognoscente" (ibidem).

\section{Entendimento versus razão dialética ${ }^{7}$}

Ao rejeitar o universal abstrato em favor da lógica concreta, Hegel e Marx também rompem, conforme visto na seção 1 , com a lógica formal, fundamentada nas categorias do entendimento (Verstand), definido por Kant (1787, p. 102) como a faculdade das regras formais do pensamento. Uma vez que as suas categorias são, conforme visto, formas abstratas, vazias, o entendimento depende da experiência sensível para dar-lhe o conteúdo, sem o qual elas não dizem nada ${ }^{8}$. Além disso, visto que são construídas abstraindo-se os elementos comuns na diversidade do sensível, pode-se dizer, com Vaz (1982, p. 3), que o entendimento representa "a faculdade dos conceitos enquanto distintos".

O pensamento analítico, próprio do entendimento, "desamarra o que está amarrado na experiência, ligado, e reduz tudo a uma classificação de conceitos; transforma aquilo que aparentemente é um caos da nossa experiência numa série ordenada de conceitos", de modo que, "[s]em análise [portanto] não podemos começar a pensar" (Vaz, 1982, p. 3). Assim,

[o] entendimento, através da negação abstrata, separa as coisas, classifica, determina; produzindo o universal abstrato (resultado do processo abstrativo do entendimento). Para Aristóteles, trata-se de um processo abstrativo que começa na experiência sensível externa, depois, passa para os sentidos internos, para a imaginação e, finalmente, para o que chamamos de inteligência ativa, que, segundo ele, produz o conceito universal, pois abstrai das particularidades que estão na experiência imediata. Já para Kant, a produção do universal

(7) Para uma discussão mais ampla deste tema, veja-se de Oliveira (2004, p. 13-90).

(8) Conforme afirma Kant (1787, p. 155), "[p]ara todo conceito requer-se, em primeiro lugar, a forma lógica, de um conceito (do pensamento) em geral e, em segundo lugar, também a possibilidade de dar-lhe um objeto, ao qual se refira. Sem esse objeto, o conceito não possui nenhum sentido e é inteiramente vazio de conteúdo". 
significa a síntese das categorias do entendimento com o que é dado na experiência através das intuições. Mas, de qualquer modo, o resultado deste universal do entendimento é sempre uma abstração, porque o essencial do entendimento é separar esse universal donde ele vem, quer dizer, da realidade sensível. Abstrato quer dizer arrancado, tirado, separado (Vaz, 1982, p. 3).

Quanto à razão, embora Kant (1787, p. 181) a conceba como "a faculdade das regras do entendimento sob princípios", é melhor defini-la como a faculdade de raciocinar segundo o princípio da necessidade ${ }^{9}$, o que, aliás, é admitido pelo próprio Kant (idem, p. 178-9), quando afirma que

em nossa razão (...) encontram-se regras fundamentais e máximas do seu uso, as quais possuem completamente o aspecto de princípios objetivos e pelos quais acontece que a necessidade subjetiva de uma certa conexão de nossos conceitos em benefício do entendimento é tomada por uma necessidade objetiva de determinação das coisas em si mesmas.

Ao apontar, assim, a necessidade subjetiva de conexão de nossos conceitos, Kant reconhece o caráter necessário da razão, que, por outro lado, não se atém aos limites da experiência, a qual transcende e supera ${ }^{10}$. Como exemplo, tem-se o requerimento de "encontrar para o conhecimento condicionado do entendimento [baseado, portanto, na realidade sensível] o incondicionado, pelo qual é completada a unidade de tal conhecimento" (ibidem, p. 183), de forma que "se o condicionado é dado [no mundo empírico], é também dada (isto é, é contida no objeto e na sua conexão) a unidade total das condições subordinadas entre si, a qual é, por conseguinte, incondicionada". Assim, tende a razão "a recolher todas as ações do entendimento, com respeito a cada objeto, a um todo absoluto" (p. 192), isto é, a remeter à totalidade das condições ${ }^{11}$.

Ocorre, porém, que, ao procurar essa totalidade, ultrapassando os limites da experiência, a razão falha, pois "a totalidade absoluta dos fenômenos é somente uma idéia [vazia]" ou seja, "um conceito necessário ao qual não pode ser dado nos sentidos nenhum objeto congruente" (idem) ${ }^{12}$, de modo que, "visto que jamais podemos projetar na imagem uma tal totalidade, permanece ela um problema sem solução" (ibidem). Pior do que isso, se

(9) Na definição de Aristóteles (Tópicos, I, 1, 100a, p. 25-26), “o raciocínio é um argumento que, estabelecidas certas coisas, outras coisas diferentes se deduzem necessariamente das primeiras".

(10) A relação entre necessidade e razão na concepção de Kant pode ser derivada da sua discussão dos princípios, que são "conhecimentos universais a priori" (Kant, 1787, p. 180), como os "axiomas da matemática (por exemplo, entre dois pontos pode haver só uma linha reta)". Em outras palavras, o necessário corresponde ao universal a priori kantiano.

(11) Veja-se, também, Kant (1787, p. 215).

(12) Essas ideias, denominadas transcendentais, "não possuem nenhuma relação com qualquer objeto que pudesse ser lhes dado congruentemente e isso por serem somente idéias" (Kant, 1787, p. 196). 
não aplicarmos nossa razão meramente a objetos da experiência, mas nos aventurarmos a estendê-la além dos limites desta, então surgem proposições dogmáticas pseudo racionais ... Cada uma dessas proposições não somente é uma contradição em si mesma, mas encontra na própria natureza da razão condições da sua necessidade, só que infelizmente a asserção do contrário possui seu lado fundamentos igualmente válidos e necessários” (KANT, 1787, p. 220-1).

Assim, por exemplo, ao se conceber o universo como totalidade, a razão chega à conclusão de que "[o] mundo tem um início no tempo e é também quanto ao espaço encerrado dentro de limites"; simultaneamente, "não possui um início nem limites no espaço, mas é infinito tanto com respeito ao tempo quanto com respeito ao espaço" (idem, p. 223).

Ao se defrontar, então, com a aparente impossibilidade de dar aos conceitos necessários da razão um "objeto congruente", assim como o caráter dialético da mesma, revelado pelas contradições em que se enreda ao tentar conceber racionalmente a realidade em si mesma - que denomina a coisa em si -, Kant concluiu que esse conhecimento está além de toda possibilidade. Em outras palavras, a razão tem a pretensão de conhecer a realidade última, mas não pode fazê-lo, de modo que o conhecimento da coisa em si permanece como um ideal irrealizável da razão. A única coisa que pode ser conhecida são os fenômenos sensíveis, apreendidos por meio das formas lógicas do entendimento. Não há, portanto, conhecimento inteiramente objetivo, pois as leis do fenômeno são dadas pelo sujeito que conhece, que vai enquadrar os fenômenos segundo suas formas lógicas - as leis conhecidas não são objetivas, pois, embora sejam conhecimento dos fenômenos, são também construções do sujeito que conhece.

Em lugar, contudo, de recuar diante da dialeticidade da razão, como o fez Kant, Hegel vai erguê-la como princípio constitutivo do método, para não dizer da própria realidade. Tomando as categorias do entendimento, que é o pensamento "que abstrai e, portanto, separa e que insiste em suas separações", comportando-se, assim, como o intelecto humano comum, que "faz prevalecer sua maneira de ver, segundo a qual a verdade teria por base a realidade sensível" (Hegel, 1912, p. 43) ${ }^{13}$, a razão dialética "resolve no nada as determinações do intelecto" e "cria o universal e nele compreende o particular" (idem, p. 29). Na verdade, das próprias categorias do entendimento emergem contradições, que ele procura superar por meio da reflexão, determinando e dividindo o concreto imediato. Contudo, "tal reflexão deve também superar suas determinações divisórias e, antes de tudo, tem de relacioná-las mutuamente" (p. 43-44), o que significa que o entendimento se transforma em razão, pois “essa relação de reflexão pertence, em si, à razão" (p. 44).

(13) "O intelecto determina e mantém firmemente as determinações" (Hegel, 1812, p. 29). 
Em outras palavras, a razão, que é dialética, ou seja, negadora, identifica as contradições entre os conceitos fixos do entendimento e rompe por meio da crítica a rigidez de suas determinações fixas. Mas, além de dialética, a razão também é positiva (ou seja, construtora), pois relaciona as particularidades das categorias do intelecto por meio da universalidade dos $\operatorname{conceitos}^{14}$.

Nas palavras esclarecedoras de Vaz (1982, p. 3):

[p]ara Hegel, a razão e o entendimento estão ligados: o entendimento é aquela força prodigiosa (Prefácio da Fenomenologia do Espírito) de negatividade que separa nesse fluxo permanente da experiência [que é a realidade sensível] e fixa o conceito das coisas, estrutura em termos de conceito o universo que nos é dado pela experiência, e a razão entra dentro desse campo do entendimento para romper, requebrar de novo essa separação. $\mathrm{O}$ entendimento toma $\mathrm{o}$ movimento real e fixa, estrutura, [o dado na experiência em] um sistema de conceitos. A razão entra dentro desse sistema e o põe novamente em movimento através das oposições que estabelece entre os conceitos.

Em outros termos, o nosso conhecimento não

pára na análise, porque se aí se detivesse, o mundo perderia o que lhe é essencial, o movimento, a vida, o novo. A razão entra (...) no domínio do entendimento para restituir ao que foi fixado, determinado, [o] movimento. Mas não vai devolver o movimento jogando tudo de novo na confusão do sensível. Vem para restituir o movimento, mas sem perder o que foi conquistado pelo entendimento: a racionalidade, o lógico, a logicidade, o sentido (idem).

Embora Marx não tenha discutido explicitamente as diferenças entre entendimento e razão dialética, as mesmas podem ser encontradas na contraposição de seus escritos com a dos economistas que o antecederam ou foram seus contemporâneos. Assim, na Introdução à Crítica da Economia Política (1857, p. 107), Marx comenta que, para esses economistas,

na produção, os membros da sociedade apropriam-se [produzem, moldam] dos produtos da natureza para as necessidades humanas; a distribuição determina a proporção dos produtos de que o indivíduo participa; a troca fornece-lhe os produtos particulares em que queira converter a quantia que lhe coube pela distribuição; finalmente no consumo, os produtos convertem-se em objetos de desfrute, de apropriação individual. A produção cria os objetos que correspondem às necessidades (Bedürfnissen); a distribuição os reparte de

(14) A questão é que, diante das contradições que emergem das categorias do intelecto, o entendimento procura, por meio da reflexão, "superar o concreto imediato, determiná-lo e dividi-lo. Mas tal reflexão deve também superar suas determinações divisórias e, antes de tudo, tem de relacioná-las mutuamente" (Hegel, 1912, Introdução, p. 43-44). Mas aí surge a contradição, pois "esta relação de reflexão pertence, em si, à razão" (Hegel, 1912, Introdução, p. 44). 
acordo com as leis sociais; a troca reparte de novo o que já está distribuído segundo a necessidade individual, e finalmente, no consumo, o produto desaparece do movimento social, convertendo-se em objeto e servidor da necessidade individual satisfazendo-a no desfrute.

Assim,

[a] produção é determinada por leis naturais gerais; a distribuição, pela contingência social, podendo, pois, influir mais ou menos favoravelmente sobre a produção; a troca acha-se situada entre ambas como movimento social formal; e o ato final do consumo, concebido não somente como o ponto final, mas também como a própria finalidade, se encontra propriamente fora da Economia, salvo quando retroage sobre o ponto inicial, fazendo com que todo o processo recomece (idem, p. 108).

Parece claro que essas considerações estão corretas, revelando certo encadeamento. No entanto, como aponta o próprio Marx (p. 108), o mesmo "é superficial". Para começar, porque, se a produção é diretamente consumo de meios de produção e de força de trabalho, o consumo propriamente dito (ou seja, fora o consumo de insumos no processo produtivo) "é também imediatamente produção" (p. 109), quando, por exemplo, o trabalhador, ao se alimentar, vestir, etc., produz a sua própria capacidade de trabalho.

A produção é, pois, imediatamente consumo; o consumo é, imediatamente, produção. Cada qual é imediatamente seu contrário. Mas, ao mesmo tempo, opera-se um movimento mediador entre ambos. A produção é mediadora do consumo, cujos materiais cria e sem os quais não teria objeto. Mas o consumo é também mediador da produção ao criar para os produtos o sujeito, para o qual são produtos (Marx, 1857, p. 109).

Em outras palavras, ao se analisar os conceitos de produção e consumo, próprios do entendimento, verifica-se que se tem uma contradição, pois ambos são, simultaneamente, diferentes e idênticos, de modo que "cada qual é imediatamente seu contrário". Essa contradição, contudo, é solucionada quando se toma em consideração o processo que as articula, em que a produção é mediadora do consumo, que, por sua vez, também é mediador da produção.

Por outro lado,

[a] articulação da distribuição é inteiramente determinada pela articulação da produção. A própria distribuição é um produto da produção, não só no que diz respeito ao objeto, podendo apenas ser distribuído o resultado da produção, mas também no que diz respeito à forma, pois o modo preciso de participação na produção determina as formas particulares da distribuição, isto é, determina de que forma o produtor participará na produção (idem, p. 112). 
Assim, embora também a produção e a distribuição sejam diferentes, não estão separadas como quer o pensamento analítico, pois o "modo preciso de participação na produção determina as formas particulares da distribuição". Desse modo, enquanto nas sociedades primitivas, onde dominava a propriedade comunal, a família do trabalhador, como membro da comunidade e coproprietária das condições de produção, tinha direito ao produto do seu trabalho, no modo de produção feudal a família camponesa era obrigada a trabalhar nas terras de seu senhor (corveia), tendo direito somente ao produto do trabalho nas terras comuns, onde criava o gado, e nas terras sob sua posse. Já no capitalismo, "um indivíduo que participe na produção por meio do trabalho assalariado, participa na repartição dos produtos, resultado da produção, na forma de salário" (Marx, 1857, p. 112), cabendo aos proprietários dos meios de produção o fruto do trabalho excedente, aquele que o trabalhador presta acima do que é necessário para reproduzir a sua força de trabalho e que recebe na forma de salário. É, pois, a posição no processo produtivo - como proprietário dos meios de produção ou como mero trabalhador nele inserido - que determina a participação do indivíduo no resultado da produção.

Como afirma Marx (1857, p. 113)

antes de ser distribuição de produtos, [a distribuição] é: primeiro, distribuição dos instrumentos de produção, e, segundo, distribuição dos membros da sociedade pelos diferentes tipos de produção, o que é uma determinação ampliada da relação anterior. (Subordinação dos indivíduos a relações de produção determinadas). A distribuição dos produtos é manifestamente o resultado desta distribuição que é incluída no próprio processo de produção, cujas articulações determina.

Finalmente, "a própria circulação é somente um momento determinado da troca, ou ainda, é a troca considerada em sua totalidade" (p. 115). E, por sua vez,

[n]a medida em que a troca é momento mediador entre a produção e a distribuição determinada por ela e o consumo, na medida em que, entretanto, este último aparece como momento da produção, a troca é também manifestamente incluída como um momento da produção (idem).

Conclui-se, então, que "uma [forma] determinada da produção determina, pois, [formas] determinadas do consumo, da distribuição, da troca, assim como relações determinadas destes diferentes fatores entre si" (ibidem). Articulam-se, assim, a produção, a distribuição, a troca e o consumo, categorias identificadas pelo entendimento, que, por se manter no âmbito do abstrato formal, não consegue resolver as contradições que surgem ao se analisá-las. Mais do que isso, ao se manter ao nível do geral, negligenciando o concreto, o pensamento analítico não discute as próprias pressuposições dessas categorias, que, no caso da Economia, dizem respeito à história. Assim, ao tomarem como dadas as formas econômicas existentes, sem 
examinar sua gênese histórica, e se aterem às características gerais da produção que são eternas - terminam por eternizar essas formas historicamente condicionadas.

Este é o caso de David Ricardo (1817), cujo sistema, segundo Zelený (1968, p. 10), guarda uma "conexão genética direta" com o sistema de $O$ Capital. Ao contrário de Adam Smith (1776), que identifica o caráter histórico do capitalismo, ${ }^{15}$ Ricardo eleva a "forma historicamente transitória de distribuição peculiar ao modo capitalista de produção a algo supra-histórico e absolutamente inalterável" (ZELENÝ, 1968, p. 19). Mais do que isso, os Princípios de Economia Política e Tributação de Ricardo começam diretamente pela análise da determinação do valor de troca das mercadorias, sem arguir em que condições (históricas, é claro) o produto do trabalho assume necessariamente essa forma. Identificando, corretamente, a quantidade de trabalho como o determinante do valor das mercadorias, não obstante, "não examina a forma - a propriedade específica do trabalho de gerar valor de troca ou de representar-se em valor de troca - o caráter desse trabalho. Daí não apreender a conexão entre esse trabalho e o dinheiro, ou a circunstância de ele ter de configurar-se em dinheiro" (Marx, 1863, p. 597).

Segundo Marx (1863, p. 597),

[o] método de Ricardo consiste no seguinte: parte da determinação da magnitude do valor da mercadoria pelo tempo de trabalho e investiga se as demais condições e categorias econômicas contradizem essa determinação ou até onde a modificam. À primeira vista percebe-se a legitimidade histórica dessa maneira de proceder, sua necessidade científica na história da economia, mas ao mesmo tempo sua insuficiência científica. A insuficiência se revela no modo de apresentação (meramente formal) e, ademais, leva a resultados errôneos, porque omite os necessários elos intermediários e procura de imediato provar a congruência entre as categorias econômicas.

Essa insuficiência de Ricardo fica patente quando ele examina em que medida os "preços naturais", ou seja, os preços que resultam da concorrência entre capitais, gerando tendencialmente uma mesma taxa de lucro em todos os setores da economia, são compatíveis com a sua tese de que "[o] valor de uma mercadoria, ou a quantidade de qualquer outra pela qual pode ser trocada depende da quantidade relativa de trabalho necessário para sua produção, e não da maior ou menor remuneração paga a esse trabalho" (Ricardo, 1817, p. 43). Para tanto, supõe uma taxa geral de lucro para realizar sua pesquisa, o que, conforme salienta Marx (1863, vol. II, p. 606) é um erro:

(15) Em inúmeras passagens da Riqueza das Nações, Smith faz referência a uma economia primitiva, em que não haveria exploração do trabalho. Assim, por exemplo, afirma que "[n]aquele estado original de coisas que precede tanto a apropriação da terra quanto o acúmulo de capital, o produto integral do trabalho pertence ao trabalhador. Este não tem nem proprietário fundiário nem patrão com quem deva repartir o fruto de seu trabalho" (Smith, 1776, p. 117) 
[e]m vez de pressupor essa taxa geral de lucro, Ricardo deveria antes ter pesquisado até onde sua existência corresponde efetivamente à determinação dos valores pelo tempo de trabalho, e teria descoberto que, ao invés de lhe corresponder, a contradiz à primeira vista, e assim teria primeiro de elucidar sua existência por meio de uma série de elos intermediários, elucidação muito diversa da subsunção pura e simples à lei do valor.

Essas considerações de Marx ilustram muito bem a forma por meio da qual a razão dialética, no dizer de Hegel, dissolve as contradições do entendimento, que "abstrai e, portanto, separa e que insiste em suas separações", "cria o universal e nele compreende o particular". Ela o faz identificando os elos intermediários necessários, as mediações, que permitem resolver a contradição entre as categorias do entendimento, no seio de uma totalidade articulada, do sistema de explicação científica da realidade. Em particular, pode-se demonstrar (veja-se Gontijo, 2009) que a teoria do valor trabalho é necessária e suficiente para se determinar a taxa de lucro, por meio da qual se explica racionalmente a formação dos "preços naturais".

\section{Do silogismo formal ao silogismo dialético}

A rejeição da lógica formal, que, conforme o testemunho de Kant (1787, p. 9), permanecera intocada desde Aristóteles, e, com a mesma, as categorias do entendimento, também significa o rompimento com o silogismo aristotélico, de forma que a dialética hegeliano-marxista promove verdadeira "ruptura epistemológica", para utilizar o conceito forjado por Gastón Bachelar ${ }^{16}$.

De saída, saliente-se que o silogismo aristotélico não serve para "construir cadeias de raciocínios que demonstram proposições de forma inequívoca" (Gontijo, 2008, p. 20), como requer a ciência. Segundo o mesmo, a premissa maior ("os homens são mortais"), que expressa a universalidade abstrata, se justapõe à premissa menor ("Sócrates é homem"), que apresenta a particularidade, possibilitando a conclusão ("Sócrates é mortal"), em que o singular se conecta ao geral pela mediação do particular. Como instrumento do pensamento, ele é, pois, forma abstrata que se aplica a todo raciocínio, de modo que a veracidade da conclusão depende inteiramente da veracidade das premissas, o que significa, pois, que a verdade permanece pressuposta desde o início, não sendo objeto de demonstração. Mais do que isto, tampouco há derivação propriamente dita, pois o termo médio (a premissa menor) não se deduz da premissa maior, de modo que a conexão entre seus termos não é necessária, deixando de satisfazer, assim, o princípio da necessidade. Em

(16) Inspirado em Bachelar, Althusser (1967) sustenta a tese, de grande apelo, de que Marx teria realizado verdadeira revolução teórica, na medida em que "fundamenta sobre um novo elemento seu pensamento teórico liberado do antigo elemento: o da filosofia hegeliana e fuerbachiana" (p. 37). Embora, como se verá na seção 7 , Marx tenha efetivamente "invertido" a filosofia de Hegel, pelo que se pode concluir de todo este texto, o método em que baseia sua obra, particularmente $O$ Capital, está embebido na dialética hegeliana, que, deste modo, efetivamente contribuiu para a ruptura cristalizada em $O$ Capital. 
outras palavras, o silogismo garante, no máximo, um discurso coerente, nunca necessário e demonstrativo. Não serve, pois, como veículo da verdade e, visto que, como sustenta o próprio Aristóteles (Retórica, I, 7, 1364b 9), “como se dispõe a ciência, assim também o verdadeiro, tampouco serve como instrumento da ciência.

De mais a mais, o reducionismo produzido pelo silogismo formal, que explica o fenômeno pela sua redução à essência, à lei geral e ao princípio abstrato, "reduz o singular ao universal abstrato e cria dois pólos entre os quais não há mediação: o individual [singular] abstrato, de um lado; o universal abstrato, de outro" (Kosík, 1963, p. 27), ou seja, os fenômenos, embora sejam incluídos em categorias genéricas como resultado de classificação formal, permanecem sem explicação. Como consequência, torna-se um veículo tautológico, que apenas serve para indicar o que há de comum entre o singular e o universal, já conhecido de antemão. Note-se que Marx (IG, 1857, p. 108) efetivamente afirma, ao examinar a relação entre produção, distribuição, troca e consumo segundo a visão dos economistas de sua época, que elas formam "um silogismo correto: a produção é a generalidade; distribuição e troca, a particularidade; consumo, a individualidade expressa pela conclusão". Todavia, reconhece que o encadeamento proporcionado pelo mesmo é "superficial", por expressar mera tautologia.

Em contraposição, pela lógica hegeliano-marxista, o particular se gesta pela particularização necessária do universal concreto, que se singulariza no indivíduo, formando o silogismo dialético, veículo de constituição da explicação científica, em lugar de tautologias superficiais. Como esclarece Ilyenkov (1960, cap. 1, p. 14), na construção hegeliana (e marxista) os conceitos "expressam não apenas o geral, mas o geral que contém os particulares, abrangendo-os em sua unidade".

Neste sentido, quando, conforme visto na seção 3, a razão penetra no domínio do entendimento, dissolvendo as separações (abstrações) por ele produzidas, o universal que emerge do próprio movimento lógico dessa dissolução racional contém em si o particular. Destarte, o processo de exposição a partir do universal concreto se dá pela sua particularização, surgindo, assim, o particular como um desdobramento do mesmo, em lugar de algo que, além da determinação comum, genérica, se diferencia do universal por uma particularidade que vem de fora (a diferença específica), como quer a lógica formal. O singular, deste modo, é o mesmo universal tornado concreto não somente em razão de suas particularidades, mas de sua individualidade, ou seja, de suas conexões singulares com a totalidade. Em outras palavras, ao se considerar algo singular, não se pode tomá-lo isoladamente como quer o pensamento analítico, mas há que se considerar necessariamente todo o complexo de relações em que o universal concreto está particularizado e singularizado. Na verdade, o universal somente existe no singular, que resulta da particularização do universal, ou, de forma que, como afirma Kojève (1947, p. 477) "a individualidade é uma síntese do particular com o universal". 
Não é, pois, sem razão que Marx (IG, p. 105) pondera que "[s]e não existe uma produção em geral, também não pode haver produção geral. A produção é sempre um ramo particular da produção - por exemplo, a agricultura, a pecuária, a manufatura, etc., - ou ela é totalidade". Mais do que isso, "a produção também não é apenas uma produção particular, mas é sempre, ao contrário, certo corpo social, sujeito social, que exerce sua atividade numa totalidade maior ou menor de ramos da produção", ou seja, está articulada de determinada maneira específica à totalidade e, como tal, é produção singular.

\section{0 método da pesquisa versus o método da exposição}

Apesar, conforme visto na seção 1, de ter rejeitado o início do estudo da Economia por uma categoria aparentemente concreta, Marx reconhece que, efetivamente, essa ciência tomou esse caminho, ou seja, começou por "uma representação caótica do todo", e, "através de uma determinação mais precisa, através de uma análise", chegou "a conceitos cada vez mais simples; do concreto idealizado" passou "a abstrações cada vez mais tênues" até ter atingido "determinações as mais simples". De fato, conforme salienta, esse teria sido

o caminho que foi historicamente seguido pela nascente economia. Os economistas do século XVII, por exemplo, começam sempre pelo todo vivo: a população, a nação, o Estado, vários Estados, etc.; mas terminam sempre por descobrir, por meio da análise, certo número de relações gerais abstratas que são determinantes, tais como a divisão do trabalho, o dinheiro, o valor, etc. (Marx, IG, 1857, p. 116).

Ressalte-se que este caminhar a partir da "representação caótica do todo" até as suas "determinações cada vez mais simples" não é acidental, mas necessário, correspondendo àquilo que Marx (1873, p. 20) denomina por método de pesquisa ou método de investigação, que, segundo ele, precisa ser distinguido do método de exposição (Dashtellung). Conforme esclarece (idem), "[a] pesquisa tem de captar detalhadamente a matéria, analisar as suas várias formas de evolução e rastrear sua conexão íntima", mostrando como se chega às categorias a partir das quais "se pode expor adequadamente o movimento real" do objeto.

O motivo é que se, como afirma Aristóteles (Ética a Nicômaco, VI, 3, 1139b, p. 31-32), "o conhecimento científico é um estado que nos torna capazes de demonstrar", de modo que a "ciência é sistema interconectado de explicação racional, ou seja, é sistema de proposições demonstradas formalmente" (Gontijo, 2008, p. 20), e, como toda demonstração se baseia em premissas, a sua dedução (ou exposição, como quer Marx) deve necessariamente começar a partir delas, construindo-se por derivação o sistema científico, o conjunto de proposições logicamente articuladas que representam o corpo da ciência. Não se pode começar, portanto, de outras categorias que não essas "premissas primeiras", para se usar a expressão aristotélica, 
pois todas as demais resultam da dedução que se baseia nos princípios fundamentais. Em outras palavras, para que ganhem inteligibilidade, todas as outras categorias possuem pressupostos que precisam ser demonstrados previamente ${ }^{17}$. Daí a pesquisa ter de, ao tomar qualquer categoria, inquirir sobre os seus pressupostos e os pressupostos desses pressupostos, até alcançar o(s) pressuposto(s) últimos, além do(s) qual(is) é impossível prosseguir. É neste sentido que, conforme citado na seção 3, Kant (1787, p. 183) afirma que a razão procura "encontrar para o conhecimento condicionado do entendimento o incondicionado, pelo qual é completada a unidade de tal conhecimento".

Neste sentido, considere-se, uma vez mais, o texto de Marx, quando discute a possibilidade de se começar a derivação da ciência econômica a partir da população. Conforme se viu na seção 1, esta categoria não serve como ponto de partida, visto tratar-se de uma abstração quando desconsideram-se seus pressupostos, ou seja, as classes sociais. Da mesma maneira, "estas classes são uma palavra vazia de sentido" se não se toma em conta "os elementos em que repousam", ou seja, seus pressupostos, como o trabalho assalariado, o capital, etc. Mas também o capital sem seus pressupostos, isto é, "sem o trabalho assalariado, sem o valor, sem o dinheiro, sem o preço, etc., não é nada". Em outras palavras, conforme se deduz do texto marxista, a pesquisa opera de forma necessária, procurando os pressupostos, os pressupostos dos pressupostos, e assim necessariamente, até se alcançar o que Kant denomina incondicionado, ou seja, aquela(s) categoria(s) que não possui(em) mais pressupostos, mas que representa(m) o(s) pressuposto(s) da exposição do sistema científico.

É claro que a concepção exposição da ciência como sistema de conhecimento demonstrativo e autofundamentado, coloca várias dificuldades, a começar pela validade das premissas sobre os quais se sustenta, ou seja, do "incondicionado" kantiano. Isto porque, conforme já afirmava Aristóteles (Tópicos, I, 1, 100a, p .26-29), uma demonstração é um raciocínio coerente em que "as premissas das quais parte são verdadeiras e primeiras, ou quando o conhecimento que delas temos provém originariamente de premissas primeiras e verdadeiras". Mas,

se, pelo princípio da necessidade, toda proposição científica deve ser demonstrada, tem-se que deve ser extraída, através de raciocínio dedutivo, das premissas que a fundamentam. Ocorre, porém, que as premissas também são proposições, que, como tais, também precisam ser provadas. Começando, assim, por qualquer proposição científica, o raciocínio tem de procurar o fundamento das premissas e, portanto, das premissas das premissas, num

(17) A inteligibilidade somente é possível em um sistema científico, ou, conforme se afirmou acima, em um conjunto de proposições logicamente articuladas.

Economia e Sociedade, Campinas, v. 25, n. 1 (56), p. 209-246, abr. 2016. 
processo sistemático que tem de prosseguir até que não existam mais premissas a serem fundamentadas (Gontijo, 2008, p. 24) ${ }^{18}$.

Isso, contudo, parece encerrar um contrassenso, na medida em que "as últimas premissas, sobre as quais se ergue todo o edifício da ciência (...) também são proposições, que, por sua vez, precisariam ser demonstradas para que satisfaçam os requerimentos da cientificidade" (Gotijo, 2008).

A solução da aporia por Aristóteles se baseou no fato de serem "necessárias as premissas todas do conhecimento científico" (Pereira, 2000, p. 129), de forma que também são necessárias as premissas primeiras, indemonstráveis. Isso ficaria claro nos Elementos de Geometria de Euclides, que "ter-se-ão inspirado da doutrina aristotélica da ciência, segundo os Analíticos, e darão aos princípios de geometria um tratamento intimamente aparentado à teoria aristotélica dos princípios da ciência" (Pereira, 2000, p. 60). De fato,

os Elementos são construídos a partir de definições, postulados e "noções comuns" (axiomas), que representam as premissas primeiras, que servem de base para a demonstração de todas as proposições, que se derivam umas das outras, em grau de complexidade crescente. Tanto os postulados quanto os axiomas são proposições necessárias, ou seja, verdades evidentes em si mesmas, que se auto-fundamentam. Com eles, estabeleceu-se definitivamente o método axiomático, que se tornaria o paradigma da ciência: toda proposição que não seja auto-evidente, como no caso dos axiomas ou postulados, tem ser neles fundamentadas, por dedução (Gontijo, 2008, p. 27).

Se com a forma da ciência como sistema interconectado de explicação racional, ou seja, como "sistema de proposições demonstradas formalmente, estando, pois, sujeita ao princípio da sistematicidade" (Gontijo, 2008, p. 20) se tornou translúcida com Elementos de Euclides, também com essa obra se tornaram patentes as dificuldades a serem enfrentadas pelas ciências da natureza. Para começar, o mundo da phýsis, que abrange a natureza e, em certa medida, o homem, está marcado pela mudança ${ }^{19}$ e pela acidentalidade, enquanto a ciência, conforme reza Aristóteles, além de ser dedutiva, e, portanto, imutável, é ciência do necessário, de modo que não há ciência do acidente (Metafísica, E, 2, 1027a, p. 19-20; K, 8, 1064b, p. 17-19; p. 30-31). De mais a mais, por ser dedutiva, a verdade científica depende de premissas primeiras cuja veracidade também precisa ser demonstrada. Ocorre que,

(18) Como diz Kant (1787, p. 13), "nas coisas em si mesmas, a razão exige o último necessariamente e com todo o direito para todo o condicionado, e mediante tal a completude da série das condições".

(19) Conforme assinala Heráclito (apud Plutarco, De E apud Delphos, 8, p. 388 E) em passagem famosa, “em rio não se pode entrar duas vezes no mesmo (...), nem substância mortal tocar duas vezes na mesma condição; mas pela intensidade e rapidez da mudança [ela se] dispersa e [se] reúne (ou melhor, nem mesmo de novo nem depois, mas ao mesmo tempo) [se] compõe e [se] dispersa, aproxima-se e afasta-se". 
aqui, no âmbito da phýsis, não se pode recorrer a enunciados necessários, como no caso dos axiomas da geometria.

Em busca da solução dessas dificuldades, Platão formulou a teoria das ideias, as quais, colocando-se acima do plano dos fenômenos, guardam "a verdadeira razão de ser do sensível" (Reale, 1991, p. 143), de forma que "o sensível só se explica com a dimensão supra-sensível, o corruptível com o ser incorruptível, o móvel com o imóvel, o relativo com o Absoluto, o múltiplo com o uno" (idem, p. 145). Segundo Platão, o pensamento que conhece a verdade segue um movimento dialético ascendente, partindo do "primeiro nível" do inteligível, ou seja, das idéias mais "próximas do sensível", em busca de suas condições e das condições dessas condições, até chegar àquilo que Platão denominava "realidades supremas e primeiras". Como sustenta Paviani (2001, p. 23), "[n]o Fédon e na República, a dialética apresenta-se como uma ascensão progressiva e sinóptica, abrangendo vários aspectos num único momento, indo do sensível ao inteligível". Nesse "procedimento dialético ascendente, livre dos sentidos e do sensível, alcançam-se as idéias e, em seguida, de idéia e idéia pode-se chegar à idéia suprema. Etapa a etapa, a multiplicidade é resolvida na unidade" (idem). Assim,

[a] dialética ascendente, synagoge (República, VI, 511, Fedro, 265 d), elevase de idéia em idéia até o não-hipotético, até alcançar (o princípio) o bem. ${ }^{20}$ Procede do múltiplo ao uno, de modo a descobrir o princípio de cada coisa, e depois o princípio dos princípios. (...). O procedimento da synagoge (no Fedro, 265 , e 266 b) indica a capacidade de discernir um traço comum que unifique coisas ou aspectos diversos. (...) No Fedro, o dialético é apresentado como aquele que pode olhar para o uno e o múltiplo. (...) Para alcançar a unificação, é preciso examinar as propriedades ou os aspectos e determinar aquilo que é comum. Nesse caso, a investigação torna-se um progredir (idem, p. 55-56).

Uma vez tendo alcançado a ideia suprema, a dialética platônica assume um movimento descendente, em que, por meio de uma cadeia de raciocínios articulados de forma necessária, se chega às ideias que dão conta dos fenômenos do mundo sensível. Nesse caminhar,

parte-se da idéia suprema ou das idéias gerais e, por divisão, distinguem-se idéias particulares contidas nas idéias gerais, e, examinando os elementos nos quais se desdobram, alcançam-se as idéias que não incluem em si outras idéias, para finalmente estabelecer o lugar de cada idéia na estrutura hierárquica do mundo" (Paviani, 2001, p. 23-24)

Essa dialética descendente, diairesis, "desenvolve-se por divisão (modalidade de análise) racional e pelas diferentes conseqüências do princípio da

(20) Platão concebe o bem como a razão última de todas as coisas, ou seja, como princípio a partir do qual, pelo movimento descendente, se constrói a totalidade da explicação racional da realidade. 
unificação sobre o qual tudo repousa. Trata-se de uma reconstrução das idéias sem recorrer à experiência" (idem, p. 56). ${ }^{21}$

Apesar de criticar a teoria das ideias de Platão, o texto da Metafísica de Aristóteles "opõe, com bastante nitidez, a ordem da investigação e da pesquisa à ordem do real e do verdadeiro saber" (Pereira, 2000, p. 119). De mais a mais, Aristóteles mantém a mesma estrutura da ciência, que

também se desdobra em uma cadeia de demonstrações necessárias, partindo das premissas primeiras, ou seja, dos princípios incondicionados, alcançados através da synagoge. Esta, por sua vez, segue o caminho inverso: parte dos sensíveis (Aristóteles, Metafísica, Z, 3, 1029b, p. 3-8), que são as coisas "mais conhecidas para nós" em busca das suas causas, isto é, das "coisas mais universais", "mais afastadas", que, em relação à inteligibilidade última do objeto, são "anteriores e mais conhecidas em absoluto" (Aristóteles, Segundos Analíticos, I, 2, 71b, 29-72a, p. 25). Tendo-se, então, alcançado as premissas primeiras, expõe-se, através da diairesis, a ordem do "real e do verdadeiro saber", fundamentando-se, por meio de demonstrações que nelas se baseiam, a explicação dos fenômenos, por elas condicionados (Gontijo, 2011).

Essa estrutura da ciência, que se viu, como toda filosofia, obscurecida pelo monopólio do pensamento da Igreja, imposto pelo édito de Juliano de 538, foi reintroduzida por Grossatesta (1168-1253), que chamou o movimento ascendente de método da resolução e o movimento descendente de método da composição ${ }^{22}$.

Tendo, a partir de então, composto a doutrina aristotélica que se difundiu na Europa Ocidental, serviu de fundamento à física de Newton, que, na Ótica (1704, p. 56-57), esclarece que, na "filosofia natural"

a investigação das coisas difíceis pelo método de análise deve sempre preceder o método da composição. Esta análise consiste em fazer experimentos e observações, e em traçar conclusões gerais deles por indução (...). Por essa maneira de análise, podemos proceder (...) dos efeitos a suas causas, e de causas particulares a causas mais gerais, até que o argumento termine no mais geral. (...) [E] a síntese consiste em assumir as causas descobertas e estabelecidas como princípios, e por elas explicar os fenômenos que procedem delas, e provar as explicações.

(21) Segundo Reale (2001, v. I, p. 226), “[o] método dialético seguido por Platão, e largamente desenvolvido pelos acadêmicos, implicava dois momentos: o que procedia do particular ao universal (procedimento universalizante) e o que procedia na busca dos constitutivos mais simples e mais elementares no mundo das Idéias e, portanto, dos elementos primeiros (procedimento elementarizante)". "Em Platão, esses métodos eram convergentes e não entravam em conflito entre si (...): os elementos primeiros e mais simples são também os mais universais, no sentido de que são condições de ser de uma esfera sempre mais vasta das coisas” (Reale, 2001, v. I, p. 238).

(22) Para Grossatesta, a resolução parte do mais particular e composto (o sensível) e ascende para o gênero mais simples e universal, enquanto a composição parte do mais universal e simples, desdobrando-se em elementos cada vez mais particulares e concretos. Veja-se Crombie (1959, p. 20-30); Losee (1979, p. 43) e Pessoa (2007, p. 36-37). 
Com efeito, os Princípios Matemáticos de Filosofia Natural estão, à maneira dos Princípios de Euclides, construídos de forma dedutiva, a partir de definições (Newton, 1686, p. 5-8), três "princípios matemáticos da filosofia natural" (idem, p. 14-15) e outros quatro "princípios", necessários para se deduzir o "sistema de mundo" (p. 17) ${ }^{23}$.

Não foi sem motivo, pois, que Hegel, identificando a base epistemológica da solução newtoniana do desafio grego, sustenta que as premissas primeiras são necessárias porque exigidas pela lógica do sistema científico que sustentam e do qual, na verdade, resultam. Destarte, o pensamento científico surge como um círculo, em que, como na Fenomenologia do Espírito (1807), o pensamento parte do sensível como certeza imediata para descobrir, por meio da reflexão, os fundamentos primeiros dessa realidade. Tendo alcançado, então, os "princípios primeiros", o pensamento retorna, por meio da exposição (Darstellung) do sistema científico, ao sensível, concebido agora como realidade efetiva (Wirklichtkeit), ou seja, como conjunto de fenômenos explicados cientificamente.

Em outras palavras, chamando o movimento do sensível representado ao universal concreto de pesquisa científica (synagoge, segundo Platão, ou método da resolução, segundo Grossatesta) e o movimento inverso de exposição (diairesis ou método da combinação), com Hegel

tem-se que a ciência se fundamenta na pesquisa científica (...), que procura, nos elementos imediatos, mais concretos e sensíveis, aquelas relações mediatas, gerais e sutis que permitem decifrar a tessitura dos fenômenos, articulados de forma lógica. O caminho da pesquisa, portanto, parte da realidade imediata, elevando-se do concreto ao abstrato, até atingir os elementos mais gerais, os princípios mesmos a partir dos quais se torna possível compreender, de forma racional, a totalidade da realidade empírica. Uma vez tendo chegado a este ponto, tem-se a exposição (Darstellung) da lógica do objeto, ou seja, a ciência, que percorre o caminho inverso ao da pesquisa, elevando-se do abstrato ao concreto, apropriando-se da realidade efetiva, reproduzindo-a como realidade pensada, explicada racionalmente (Gontijo, 2008, p. 78).

(23) Estes três "princípios matemáticos da filosofia natural, que descreve os movimentos verdadeiros dos corpos no Espaço Absoluto" são os seguintes: (i) "[t]odo corpo permanece em seu estado de repouso ou de movimento uniforme em linha reta, a menos que seja obrigado a mudar seu estado por forças impressas nele" (a lei da inércia); (ii) "[a] mudança do movimento é proporcional à força motriz impressa, e se faz segundo a linha reta pela qual se imprime essa força"; (iii) "[a] uma ação sempre se opõe uma reação igual, ou seja, as ações de dois corpos um sobre o outro sempre são iguais e se dirigem a partes contrárias" (a lei de ação e reação) (Newton, 1686, p. 14-15). Para "a constituição do sistema de mundo", ainda seriam necessárias as seguintes "regras": (i) "[n]ão se hão de admitir mais causas das coisas naturais do que as que sejam verdadeiras e, ao mesmo tempo, bastem para explicar os fenômenos de tudo" (a "navalha de Ockham"); "[l]ogo, os efeitos naturais da mesma espécie têm as mesmas causas"; (iii) "[a]s qualidades dos corpos que não admitem intensificação nem remissão de graus, e que se verificam, dentro da nossa experiência, como pertencentes a todos os corpos, devem ser julgadas qualidades universais de todos e quaisquer corpos"; (iv) "[o] centro do sistema do mundo está em repouso" (idem, p. 18). 
Figura 2

O círculo da pesquisa e da exposição da ciência

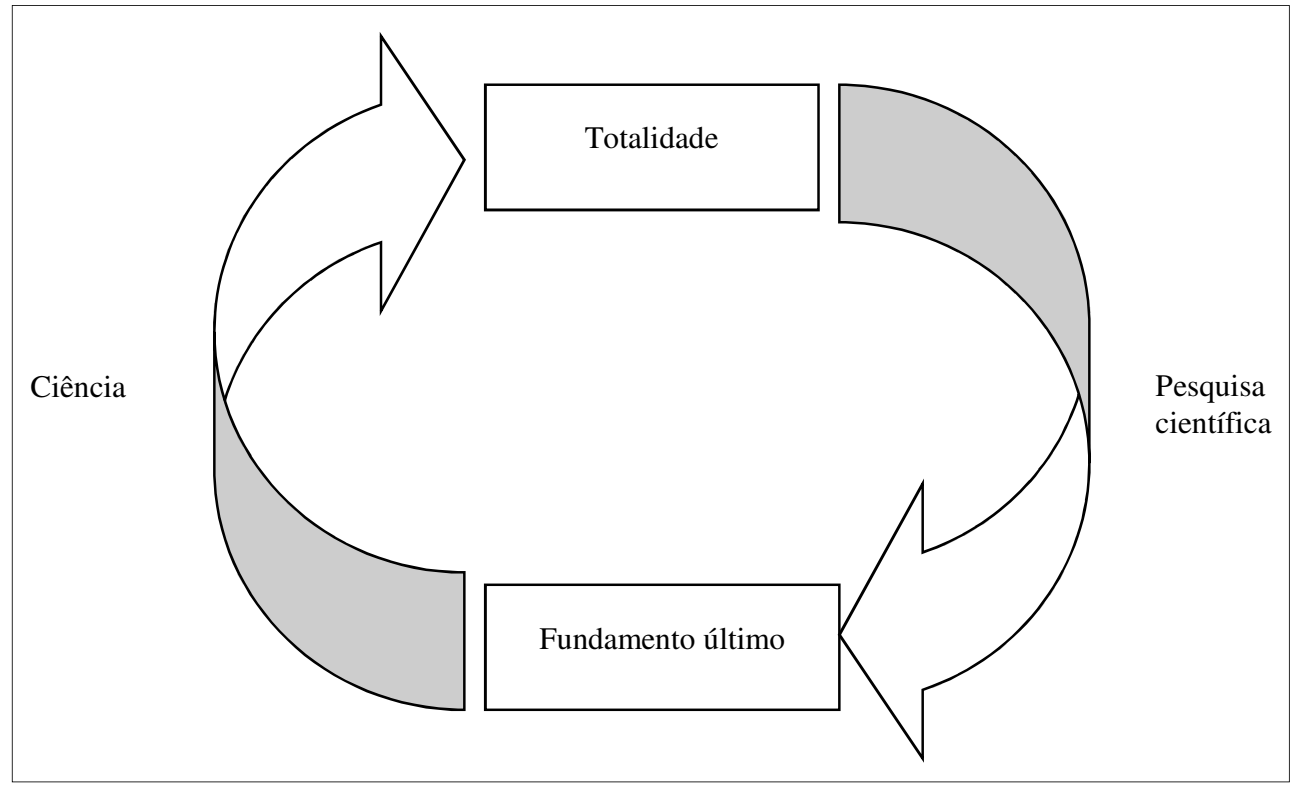

Conforme visto, essa concepção também foi esposada por Marx (1873, p. 20), que no Prefácio da Segunda Edição de $O$ Capital, afirma que "[s]ó depois de concluído [o] trabalho [da pesquisa] é que se pode expor adequadamente o movimento real" do objeto, através da exposição (Dashtellung).

Assim, se, começando pela população, a qual forneceria "uma representação caótica do todo", e, "através de uma análise, chegaríamos a conceitos cada vez mais simples (...) até atingirmos determinações mais simples", ou seja, as "relações gerais abstratas que são determinantes", "teríamos que voltar a fazer a viagem de modo inverso, até dar de novo com a população, mas desta vez não como uma representação caótica de um todo, porém, como uma rica totalidade de determinações e relações diversas" (Marx, IG, p. 116). Por meio desse caminho, que "é manifestamente o método cientificamente exato" (idem),

[e]stes elementos isolados, uma vez mais ou menos fixados e abstraídos, dão origem aos sistemas econômicos, que se elevam do simples, tal como trabalho, divisão do trabalho, necessidade, valor de troca, até o Estado, a troca entre as nações e o mercado mundial (ibidem).

Portanto, conforme elucida Kosík (1963, p. 31), "[a]quilo de onde a ciência inicia a própria exposição já é resultado de uma investigação e de uma apropriação crítico científica da matéria”. Não é, portanto, por acaso que Marx começa $O$ Capital pela mercadoria, até porque se "[o] início da investigação é casual e arbitrário, (...) o início da exposição é necessário" (idem), correspondendo a aquela categoria que 
constitui o ponto de partida do desdobramento da Dashtellung do capitalismo. Em outras palavras, a mercadoria, que não tem pressupostos outros que a própria totalidade da qual é síntese, representa o pressuposto do sistema do qual é o fundamento último, constituindo, pois, a base do sistema de explicação da economia de mercado dos dias de hoje, fundamentada no trabalho assalariado.

\section{Da dialética idealista dos conceitos à reprodução ideal do concreto}

Embora possa parecer, a partir do exposto nas seções anteriores, que o método marxista seja derivado direta e linearmente de Hegel, devem ser assinaladas importantes diferenças entre os dois, mesmo tomando-se em conta que o ponto de partida marxista "é nitidamente - ainda que desde os inícios em termos críticos - a filosofia hegeliana" (Lukács, 1971a, p. 11). É claro que, para o marxismo vulgar, essas diferenças são evidentes e gritantes, na medida em que o método hegeliano estaria, segundo o jargão popular, de cabeça para baixo - enquanto Marx partiria do material para o ideal, Hegel caminharia no sentido oposto.

Para o estudioso, contudo, o assunto parecerá mais difícil, não apenas porque, conforme demonstrado extensivamente, muitas das formulações marxistas são bem próximas das hegelianas, mas em razão do método de pesquisa e o método da exposição científica - que se pressupõem mutuamente - constituírem um círculo que não possui pressupostos externos. Se, portanto, a dialética de Hegel possui um caráter esférico (ou circular), segue-se que sua inversão não deve produzir qualquer resultado aparente, pois, afinal, em uma esfera com gravidade própria como o sistema hegeliano de ciência não há em cima nem em baixo. De mais a mais, a identificação das semelhanças e diferenças entre as duas esbarra, em grande medida, na diversidade dos objetos, de modo que não se torna claro até que ponto as divergências se originam em considerações metodológicas ou se devem a objetos distintos. Outro empecilho reside na amplitude e complexidade dos escritos de Hegel e de Marx, o que torna difícil avaliá-los em seu conjunto, pré-requisito fundamental para um sólido julgamento do ponto de vista metodológico.

É claro que, quando se acompanha os Grundrisse e $O$ Capital, verifica-se que não há, em Marx, uma dialética estritamente conceitual, não apenas porque o desdobramento das categorias se dá a partir da práxis humana, mas devido ao fato de a exposição necessitar de pressupostos históricos que não desenvolve. Tome-se, assim, como exemplo, a gênese do dinheiro, a partir da dialética das formas do valor; apesar de Marx não fazer esta analogia, parece claro que a forma acidental do valor corresponde, historicamente, às primeiras trocas, que obviamente assumiram caráter fortuito até que se desenvolvessem, possibilitando que alguns produtos (gado, chá, etc.), assumissem o papel de forma equivalente. $\mathrm{O}$ desenvolvimento histórico das trocas e, portanto, da circulação mercantil, é que induz à emergência da forma geral; do mesmo modo, quando uma mercadoria, como o ouro ou a prata, assume o monopólio de equivalente geral, gera-se a forma dinheiro. Em suma, só há o 
desenvolvimento das formas do valor, desembocando no dinheiro, em razão da ação humana histórica. O que não significa, por certo, que a atuação humana na troca pudesse gerar algo de distinto do que já está presente na lógica embutida (mais ainda não realizada) da mercadoria. Não foram os homens que, deixados ao seu arbítrio, construíram a lógica mercantil; antes, foi a reiteração das trocas pelos homens que fez desabrochar essa lógica.

Embora essa colocação seja importante, no sentido de demarcar mais claramente a natureza materialista da dialética marxista, em um ponto a lógica mercantil, exacerbada pela circulação de mercadorias promovida pelos homens, não leva, por si mesma, à sua conclusão lógica, ou seja, ela não produz o modo de produção capitalista. Isto porque, apesar do dinheiro ser capital em si (1867, v. I, p. 125-131), na medida em que se transforma na finalidade da circulação mercantil, ele não consegue se transformar em capital para si, em sujeito do processo de reprodução social, na medida em que não põe seus próprios pressupostos. Afinal, para que a acumulação de capital não dependa de pressupostos externos, o próprio processo de produção tem de se transformar em processo de valorização do capital, o que requer que a força de trabalho seja uma mercadoria, pois só assim o valor que incorpora nos produtos de seu trabalho é maior do que o valor incorporado aos bens e serviços necessários à sua reprodução. Ocorre que, originariamente, "o sujeito trabalhador é um indivíduo natural, um ser natural" (Marx, 1857-1858b, p. 93) e, desse modo, encontra na natureza, de forma imediata, os meios de produção, isto é, as condições objetivas de seu trabalho. Há, portanto, que ocorrer a separação do trabalhador dessas condições para que o capital possa tornar-se sujeito autônomo. E isso, por sua vez, não é produto da circulação mercantil ou do dinheiro, de modo que a "dedução" da totalidade concreta (o capitalismo) a partir do universal concreto (a mercadoria) não pode prosseguir. Em um falar hegeliano, o desenvolvimento imanente do conceito não se fez possível, por esbarrar em pressupostos externos que não gera nem subsume. Definitivamente, não há uma dialética idealista de conceitos.

Por outro lado, adicione-se que Marx (IG, 1857, p. 117) assinala que, tendo em vista que, pelo método da exposição, "as determinações abstratas conduzem à reprodução do concreto por meio do pensamento", Hegel teria caído

na ilusão de conceber o real como resultado do pensamento que se sintetiza em si, se aprofunda em si, e se move por si mesmo; enquanto que o método que consiste em elevar-se do abstrato ao concreto não é senão a maneira de proceder do pensamento para apropriar-se do concreto, para reproduzi-lo como concreto pensado. Mas este não é de modo nenhum o processo da gênese do próprio concreto. A mais simples categoria econômica, por exemplo, o valor de troca, pressupõe a população, uma população produzindo em determinadas condições e também certos tipos de famílias, de comunidades ou Estados. O valor de troca nunca poderia existir de outro modo senão como relação unilateral, abstrata de um todo vivo e concreto já dado. 
Ocorre que,

[c] ]omo categoria, ao contrário, o valor de troca leva consigo um modo de ser antediluviano. Para a consciência - e a consciência filosófica é determinada de tal modo que, para ela, o pensamento que concebe é o homem efetivo, e o mundo concebido é como tal o único efetivo. Para a consciência, pois, o movimento das categorias aparece como o ato de produção efetivo - que recebe infelizmente apenas um impulso do exterior -, cujo resultado é o mundo, e isto é certo (aqui temos de novo uma tautologia) na medida em que a totalidade concreta, como totalidade de pensamento, como um concreto de pensamentos, é de fato um produto do pensar, do conceber; não é de modo nenhum o produto do conceito que pensa separado e acima da intuição e da representação, e que se engendra a si mesmo, mas da elaboração da intuição e da representação em conceitos. $\mathrm{O}$ todo, tal como aparece no cérebro, como um todo de pensamentos, é um produto do cérebro pensante que se apropria do mundo do único modo que lhe é possível, modo que difere do artístico, religioso e prático-mental de se apropriar dele. O sujeito real permanece subsistindo, agora como antes, em sua autonomia fora do cérebro, isto é, na medida em que o cérebro não se comporta se não especulativamente, teoricamente. Por isso também, no método teórico [da economia política], o sujeito - a sociedade - deve figurar sempre na representação como pressuposição (idem).

Apesar da afirmativa de que "[o] sujeito real permanece subsistindo, agora como antes, em sua autonomia fora do cérebro" sugerir indevidamente que Hegel concebe que a realidade surge do pensamento, nada mais acima sugere que o filósofo tenha caído na ilusão de que "o conceito de cão ladra", como se, para ele, os pensamentos deixassem de ser abstrações mentais para, por um processo mágico e místico, adquirirem realidade concreta. Antes, Marx argui que, diferentemente de Hegel, o processo de reprodução da realidade pelo pensamento, ou seja, a exposição da totalidade a partir do universal concreto difere de sua gênese real. Parece indicar, destarte, que a dialética marxista traz uma concepção distinta, pois, em lugar de representar a gênese ontológica do real, expõe sua reprodução racional, como realidade pensada cientificamente ${ }^{24}$. A famosa inversão da dialética hegeliana, portanto, não se daria ao nível metodológico, mas do sujeito do processo: enquanto para Hegel, como idealista, é o espírito absoluto que comanda as transformações da realidade, objetivando-se na natureza e subjetivando-se no homem que reflete sobre ambos, para Marx, como materialista, as leis do devir estão na própria natureza, independentemente do homem, que apenas as apreende pela razão ${ }^{25}$.

(24) Para Fausto (1983), a dialética marxista se diferencia da hegeliana por incorporar as ciências modernas, que pertencem ao campo do entendimento. Por extrapolar os objetivos deste artigo, abstém-se, aqui, de apontar os erros dessa perspectiva. Tampouco serão comentados os problemas que podem sem identificados em Fausto (1997).

(25) Aparentemente, a abordagem marxista cria uma dificuldade para se conceber a história como processo necessário. A superação dessa dificuldade, contudo, é possível por meio do conceito de modo de produção. Veja-se Gontijo (1982). 
A questão, todavia, é mais complexa, até porque não parece fácil distinguir a gênese do real a partir da categoria mais simples da sua reprodução como realidade pensada seguindo o mesmo caminho. Nesse sentido, o exemplo de Marx é esclarecedor: se a explicação do capitalismo se inicia necessariamente pela mercadoria e, portanto, pelo valor, o mesmo não se pode dizer da sua gênese, a qual, embora pressuponha a expansão do mercado, tem outros pré-requisitos históricos não postos pelo próprio desenvolvimento da produção mercantil e do dinheiro. Tanto assim que, na Antiguidade, na Idade Média e no período do renascimento do comércio, a explicitação da lógica do capital, latente no valor cristalizado no dinheiro, se viu obstruída pela inexistência da mercadoria força de trabalho. Embora, portanto, o valor como categoria leve consigo "um modo de ser antediluviano", antes do capitalismo surge apenas "como relação unilateral, abstrata de um todo vivo e concreto já dado", cuja lógica lhe era estranha.

Não é sem motivo, pois, que ilustra Marx (IGE, p. 118), que

embora o dinheiro tenha, muito cedo e por toda parte, desempenhado um papel, não assume papel de elemento dominante na Antiguidade, senão de modo unilateral e em determinadas nações - as nações comerciais. E mesmo na Antiguidade mais culta, entre os gregos e os romanos, não atinge seu completo desenvolvimento, que se pressupõe existir na moderna sociedade, a não ser no período de sua dissolução. Esta categoria, que é, no entanto, bem simples, só aparece, portanto, historicamente com todo o seu vigor nos Estados mais desenvolvidos da sociedade. E o dinheiro não entrava de modo nenhum em todas as relações econômicas; assim, no Império Romano, na época de seu perfeito desenvolvimento, permaneceram como fundamento o imposto e as entregas em produtos. $\mathrm{O}$ sistema do dinheiro, propriamente dito, encontravase completamente desenvolvido apenas no exército, e jamais atingiu a totalidade do trabalho. De modo que, embora a categoria mais simples possa ter existido historicamente antes da mais concreta, pode precisamente pertencer em seu pleno desenvolvimento, intensivo e extensivo, a formas complexas de sociedade, enquanto que a categoria mais concreta já se achava plenamente desenvolvida em uma forma de sociedade menos avançada.

De igual forma, "[o] trabalho parece ser uma categoria muito simples. E também a representação do trabalho neste sentido geral - como trabalho em geral é muito antiga. Entretanto, concebido economicamente nesta simplicidade, o 'trabalho' é uma categoria tão moderna como o são as relações que engendram esta abstração" (Marx, idem, p. 118-119). De fato,

[a] indiferença em relação ao gênero de trabalho determinado pressupõe uma totalidade muito desenvolvida de gêneros de trabalho efetivos, nenhum dos quais domina os demais. Tampouco se produzem as abstrações mais gerais senão onde existe o desenvolvimento concreto mais rico, onde um aparece como comum a muitos, comum a todos. Então já não pode ser pensado somente 
sob uma forma particular. Por outro lado, esta abstração do trabalho em geral não é apenas o resultado intelectual de uma totalidade concreta de trabalhos. A indiferença em relação ao trabalho determinado corresponde a uma forma de sociedade na qual os indivíduos podem passar com facilidade de um trabalho a outro e na qual o gênero determinado de trabalho é fortuito, e, portanto, élhes indiferente. Neste caso o trabalho se converteu não só como categoria, mas na efetividade em um meio de produzir riqueza em geral, deixando, como determinação, de se confundir com o indivíduo em sua particularidade. Este estado de coisas se encontra mais desenvolvido na forma de existência mais moderna da sociedade burguesa - nos Estados Unidos. Aí, pois, a abstração da categoria 'trabalho', 'trabalho em geral', trabalho sans phase (sem rodeios), ponto de partida da Economia moderna, torna-se pela primeira vez praticamente verdadeira. Assim, a categoria mais simples, que a Economia moderna situa em primeiro lugar e que exprime uma relação muito antiga e válida para todas as formas de sociedade, só aparece no entanto nesta abstração praticamente verdadeira como categoria da sociedade mais moderna (p. 119120).

Não se pense, contudo, que Hegel tenha confundido a gênese lógica a partir da categoria mais simples com o desenvolvimento histórico, até porque "o que se desenvolve sobre bases históricas não se pode confundir com o desenvolvimento a partir do conceito [ou seja, teoricamente, pela exposição que começa pelo universal concreto], nem a legitimação e explicitação históricas atingem jamais o alcance de uma justificação em si e para si” (Hegel, 1820, p. 21). A crítica marxista, porém, é de outra estirpe e até mais abrangente do que a explicação acima deixa transparecer não somente porque, como diz Lukács (1971a, p. 18), “o processo ontológico do ser e da gênese é aproximado em demasia do processo (necessário no plano cognitivo) da concepção".

O problema é que, por conceber de modo idealista a realidade e a história, Hegel não cumpriu o seu próprio desiderato de deixar-se embriagar e conduzir pela lógica do concreto. Como resultado, conforme apontou Marx em inúmeras oportunidades, forçou a realidade concreta para que essa se enquadrasse na sua dialética, caindo, portanto, no erro de torná-la um instrumento, tal como a lógica formal que criticara. Assim, por exemplo, na Filosofia do Direito, Hegel (1920, p. 29) parte da vontade indeterminada e, portanto, indefinida, da "liberdade do vazio", para, por meio da sua particularização, concretizar a vontade do sujeito que quer, a qual desemboca na individualidade, como autodeterminação do sujeito, o que implicaria seu relacionamento com a natureza. O direito começaria, portanto, por existir na forma da posse, que surgiria do "direito de apropriação que o homem tem sobre todas as coisas" (Hegel, idem, p. 58). Apesar de que, segundo Marx (IG, p. 117-119), seja correto conceber "a posse como a mais simples relação jurídica do sujeito", Hegel erra, pois 
não existe posse anterior à família e às relações senhor e servo, que são relações muito mais concretas ainda. Ao contrário, seria justo dizer que existem famílias, tribos, que se limitam a possuir, mas não têm propriedade. A categoria mais simples aparece, pois, como relação de comunidade mais simples de famílias ou tribos, em comparação com a propriedade. Na sociedade mais desenvolvida aparece como a relação mais simples de um organismo mais desenvolvido, mas é sempre pressuposto o substrato mais concreto, cuja relação é a posse. Podese imaginar um selvagem isolado possuindo coisas. Mas neste caso a posse não é uma relação jurídica.

Em outras palavras, a propriedade privada não surge do desdobramento da vontade individual, até porque, como demonstra o estudo da história, essa estava, nas origens da sociedade, condicionada pela comunidade, que "surge a partir da evolução espontânea (naturwüchsig): a família, a tribo formada pela ampliação da família ou pelos casamentos entre famílias, e combinações de tribos" (Marx, 18571858 b, p. 66). Portando, a comunidade tribal, o grupo natural, surge "como a condição prévia da apropriação e uso conjuntos (...) do solo" (idem).

As relações do homem com a terra são ingênuas: eles se consideram como seus proprietários comunais, ou seja, membros de uma comunidade que se produz e reproduz pelo trabalho vivo. Somente na medida em que o indivíduo for membro de uma comunidade como esta - literal e figuradamente - é que se considerará um proprietário ou possessor. Na realidade, a apropriação pelo processo de trabalho se dá sob essas pré condições que não são produto do trabalho, mas parecem ser seus pressupostos naturais ou divinos (idem, p. 67).

$\mathrm{Na}$ verdade, a questão é mais ampla, pois Hegel não tomou em conta que "[o] homem é no sentido mais literal, [como queria Aristóteles,] um zoon politikon" (Marx, IG, p. 104), de modo que o indivíduo, de onde parte a análise hegeliana, é uma abstração no sentido negativo do termo, que, assim como "[o] caçador e o pescador, individuais e isolados, de que partem Smith e Ricardo", também pertence "às pobres ficções robinsonadas do século XVIII" (idem, p. 103). Desse modo, "[o]s profetas do século XVIII, sobre cujos ombros e apoiaram inteiramente [não apenas] Smith e Ricardo", mas também, como conclui Hegel, "imaginaram este indivíduo do século XVIII (...) como um ideal, que teria existido no passado. Vêem-no não como um resultado histórico, mas como ponto de partida da História, porque o consideravam como um indivíduo conforme à natureza" (ibidem) ${ }^{26}$. Nesse sentido, "Hegel pressupõe o individuo em geral, abstraído da sociedade em que realmente vive" (Uchida, 1988, p. 28). A origem da propriedade privada, assim, não pode ser procurada na vontade individual, livre e imediata, que, como tal, desconectada da comunidade, somente surgirá, ainda assim como aparência, na moderna sociedade

(26) Não é sem motivo, pois, que o ponto de partida de Marx (IG, p. 103) é "a produção dos indivíduos determinada socialmente". 
burguesa, em que, pelo contrário, "as relações sociais (e, deste ponto de vista, gerais) alcançaram o mais alto grau de desenvolvimento" (p. 104). Daí a acusação de idealismo, no sentido pejorativo do termo, ou seja, de distanciamento da realidade concreta, de deixar de lado o mergulho na dialética do concreto. Daí também a acusação de que Hegel, em lugar de uma atitude "contemplativa", ou seja, de seguir a dialética da própria realidade, teria transformado seu método em um organizador da mesma, à maneira do entendimento kantiano, que pretende moldar o fenômeno a partir de suas categorias a priori.

\section{A anatomia do homem é chave para a anatomia do macaco}

Embora a seção 6 possa ter dado uma primeira noção a respeito da diferença entre o materialismo marxista e o idealismo hegeliano, certamente que deixou em aberto outra questão igualmente espinhosa - a existência histórica de categorias que somente se inserirão de forma orgânica em uma totalidade historicamente posterior. Como pergunta Marx (IG, p. 117), as categorias mais simples "não possuem também uma existência independente histórica ou natural anterior às categorias mais concretas?"

De saída, Marx (idem, p. 122) esclarece que seria "impraticável e errôneo colocar as categorias econômicas na ordem segundo a qual tiveram historicamente uma ação determinante", visto que "[a] ordem em que se sucedem [do ponto de vista lógico] se acha determinada, ao contrário, pelo relacionamento que têm umas com as outras na sociedade burguesa moderna, e que é precisamente o inverso do que parece ser uma relação natural, ou do que corresponde à série do desenvolvimento histórico" (ibidem).

O motivo é que essa sociedade representa a totalidade desenvolvida, que constitui a chave para a compreensão da sua pré-história, ou seja, da história da sua formação no tempo, assim como de todas as totalidades anteriores, não acabadas, por não terem esgotado o desenvolvimento que se processou a partir do universal concreto. Como afirma Marx (IG, p. 120)

[a] sociedade burguesa é a organização histórica mais desenvolvida, mais diferenciada da produção. As categorias que exprimem suas relações, a compreensão de sua própria articulação, permitem penetrar na articulação e nas relações de produção de todas as formas de sociedade desaparecidas, sobre cujas ruínas e elementos se acha edificada, e cujos vestígios, não ultrapassados, ainda leva de arrastão desenvolvendo tudo que fora antes apenas indicado que toma assim toda a sua significação, etc. A anatomia do homem é uma chave para a anatomia do maçado. ${ }^{27} \mathrm{O}$ que nas espécies animais inferiores indica uma

(27) A tradução de Giannotti reza que "a anatomia do homem é a chave da anatomia do maçado"; todavia, acatou-se a sugestão do revisor, segundo a qual a tradução mais adequada é a do texto acima.

Economia e Sociedade, Campinas, v. 25, n. 1 (56), p. 209-246, abr. 2016. 
forma superior não pode, ao contrário, ser compreendido senão quando se conhece a forma superior. A Economia burguesa fornece a chave da Economia da Antiguidade, etc.

Tome-se, assim, para começar, o dinheiro. Na sociedade capitalista - a sociedade mercantil, por excelência -, o tecido social é construído a partir das relações de troca, que permitem que os indivíduos se insiram no processo de reprodução da sociedade. $\mathrm{E}$ as relações de troca envolvem necessariamente $\mathrm{o}$ dinheiro; mais do que isso, visto que o capital é o dinheiro com a finalidade de gerar mais dinheiro, o dinheiro representa, por assim dizer, o alfa e o ômega dessa organização social. Mas "[o] dinheiro pode existir, e existiu historicamente, antes que existisse o capital, antes que existissem os bancos, antes que existisse o trabalho assalariado" (Marx, IG, 1857, p. 118). Todavia,

embora o dinheiro tenha, muito cedo e por toda parte, desempenhado um papel, não assume papel de elemento dominante na Antiguidade, senão de modo unilateral e em determinadas nações - as nações comerciais. E mesmo na Antiguidade mais culta, entre os gregos e romanos, não atinge seu completo desenvolvimento, que se pressupõe existir na sociedade burguesa, a não ser no período de sua dissolução. Esta categoria, que é, no entanto, bem simples, só aparece, portanto, historicamente com todo se vigor nos Estados mais desenvolvidos da sociedade [, isto é, nas nações capitalistas da modernidade] (idem)

De igual forma, "[o] trabalho parece ser uma categoria muito simples. (...). Entretanto, concebido economicamente nesta simplicidade, o 'trabalho' é uma categoria tão moderna como o são as relações que engendram esta abstração" (ibidem, p. 118-119). De fato,

[a] indiferença em relação ao gênero de trabalho determinado pressupõe uma totalidade muito desenvolvida de gêneros de trabalho efetivos, nenhum dos quais domina os demais. Tampouco se produzem as abstrações mais gerais senão onde existe o desenvolvimento concreto mais rico, onde um aparece como comum a muitos, comum a todos. Então já não pode ser pensado somente sob uma forma particular. Por outro lado, esta abstração do trabalho em geral não é apenas o resultado intelectual de uma totalidade concreta de trabalhos. A indiferença em relação ao trabalho determinado corresponde a uma forma de sociedade no qual os indivíduos podem passar com facilidade de um trabalho a outro e na qual o gênero determinado de trabalho é fortuito,e, portanto, é-lhes indiferente. Nesse caso o trabalho se converteu não só como categoria, mas na efetividade em um meio de produzir riqueza em geral (Marx, IG, 1857, p. 119).

Essa "abstração em ato", ou seja, essa abstração que é produto efetivo da sociedade, tornando, pois, possível a sua construção pelo pensamento, também é fruto do capitalismo, que gerou o denominado trabalho abstrato, isto é, indiferente em relação ao seu conteúdo concreto. Por isso, "até as categorias mais abstratas precisamente por causa de sua natureza abstrata -, apesar da sua validade para todas 
as épocas, são, contudo, na determinidade desta abstração, igualmente produto de condições históricas e dentro dos limites destas" (idem, p. 120).

Enfim, são por essas razões que afirma Hegel (1820, p. 16), em passagem famosa, que

a filosofia chega sempre muito tarde. Como pensamento do mundo, só aparece quando a realidade efetuou e completou o processo de sua formação. $\mathrm{O}$ que o conceito ensina, mostra-o a História com a mesma necessidade: é na maturidade dos seres que o ideal se ergue em face do real, e depois de ter apreendido o mundo na sua substância, reconstrói-o na forma de um império de idéias. Quando a filosofia chega com a sua luz crepuscular a um mundo já a anoitecer, é quando uma manifestação de vida está prestes a findar. Não vem a filosofia para a rejuvenescer, mas apenas reconhecê-la. Quando as sombras da noite começam a cair é que levanta o vôo a ave de Minerva. ${ }^{28}$

\section{Da introdução aos Grundrisse ao capital como sujeito}

Com base nas seções anteriores, não parece difícil concluir que a IG representa "momento importante, e sob certos aspectos insubstituível, de explicitação do método especificamente marxiano de elaboração da crítica da economia política" (De Paula, 2010, p. 89). Não obstante, cotejando-a tanto com o resto dos Grundrisse quanto com $O$ Capital, parece clara a sua natureza inacabada, por omitir dimensões decisivas da dialética marxista, conforme transparece nessas obras.

Apesar de não haver espaço aqui para examinar a questão em profundidade, cabe salientar que, em primeiro lugar, Marx não discute a questão da totalidade, considerada por Lukács (1919-22, p. 41) como o reino "portador do princípio revolucionário da ciência". Marx assinala que, no caso da Economia Política, "se começássemos pela população, teríamos uma representação caótica do todo", ou seja, teríamos a totalidade da representação; também demonstra que, por meio da pesquisa, se chega ao ponto de partida da exposição. Porém, não mostra que o resultado da mesma é a totalidade concreta, ou totalidade sistemática, que, conforme esclarece Kosik (1963, p. 26), é "um todo que possui sua própria estrutura (e que, portanto, não é caótico), que se desenvolve (e, portanto, não é imutável nem dado uma vez por todas), que se vai criando (e que, portanto, não é um todo perfeito e acabado no seu conjunto e não é mutável apenas em suas partes isoladas, na maneira de ordená-las)". ${ }^{29}$

(28) Na tradução de Vitorino, lê-se "pássaro de Minerva". Optou-se por "ave de Minerva" dado que a expressão assim foi consagrada.

(29) "O verdadeiro é o todo" (Hegel, 1807, p. 13). "A verdade é a totalidade da realidade que se revela plena e completamente a si; é a absolute Idee (idéia absoluta), o konkreter Begriff (conceito concreto)” (Kojève, 1947, p. 42). 
Tampouco aborda Marx o papel da contradição, que, como no caso da Lógica de Hegel, é o que viabiliza a "dedução" que se processa a partir do universal concreto (a mercadoria), de cuja particularização emerge a totalidade ( $O$ Capital). Em Aristóteles, este papel cabe ao silogismo formal, que, como visto na seção 4, não é veículo da ciência, e à dedução axiomática, que também não é aceitável, por romper com o princípio da necessidade, ao admitir diferentes maneiras de se provar os teoremas. Já em Hegel, que, ao contrário de Kant, não recuou ao identificar a natureza contraditória da razão, a contradição se torna o princípio de demonstração, que prossegue, como em $O$ Capital, por meio da solução das contradições que se sucedem até que se chegue à totalidade.

Nesta demarche, "[a]s configurações do capital (...) aproximam-se (...) gradualmente, da forma em que elas mesmas aparecem na superfície da sociedade, na interação dos diversos capitais, na concorrência e ainda na consciência costumeira dos próprios agentes de produção" (Marx, 1994, Liv. III p. 29-30). Terminam por assumir, assim, como examinado no Livro III de $O$ Capital, um status ontológico distinto das formas do capital correspondentes aos níveis que o antecedem logicamente, ou seja, à produção imediata, analisada no Livro I e à circulação (Livro II). Trata-se, na verdade, "do momento do aparecer da essência - o trabalho humano abstrato substancializado como capital - no domínio da exterioridade, ou seja, do fenômeno" (Gontijo, 2013, p. 20), concebido por Hegel (1812, p. 345-349) como forma do aparecer da essência ao nível do imediato, contendo, portanto, uma dimensão de mera aparência. Enfim, os valores (nível da essência) governam os preços de mercado (nível fenomênico) por meio da sua gravitação em torno dos preços de produção, configurando a explicação racional da realidade efetiva, a Wirklichtkeit hegeliana, "concebida como emergência da essência ao nível do fenômeno, englobando o âmbito da acidentalidade, inescapável em toda ciência empírica" (Gontijo, idem, p. 24).

Mas se o movimento da essência à realidade efetiva está ausente na IG, também se omite que toda exposição como Darstellung é necessariamente crítica, ${ }^{30}$ não somente por resolver as contradições do entendimento, identificando o termo médio (o universal), como Marx faz ao apontar os erros dos economistas contemporâneos ou que o precederam, mas porque, no desdobramento construtivo da totalidade a partir do universal concreto, cada momento representa, por assim dizer, a crítica do anterior, que conteria as contradições que permitiram o avanço da exposição. De mais a mais, visto que "[s]ó o todo", como quer Hegel, "possui realidade concreta" (Kojève, 1947, p. 36), a sua exposição permite identificar a

(30) “A análise do elemento 'exposição' no método dialético d' O Capital não pode, em nenhum momento, levar ao esquecimento de que a exposição das categorias da economia política está indissoluvelmente unida à [sua] crítica" (Müller, 1982, p. 19). 
unilateralidade de toda construção teórica sobre o objeto e, por conseguinte, realizar a sua crítica.

Outra importante ausência na IG é da tese de Hegel (1807, p. 12) de que há de se "apreender e exprimir o verdadeiro não [apenas] como substância, mas exatamente na mesma medida como sujeito". Apesar de Luckács (1971b, p. 41) afirmar que, nesta tese, "não há dúvida que [Hegel] entende o conhecimento completo (absoluto) da substância pelo sujeito", Marx efetua a "retransformação da substância em sujeito" no plano ontológico do capital, sem que ocorra nenhum "milagre místico", como receia Lukács (idem). De fato, partindo da análise da mercadoria, Marx mostra que o trabalho socialmente necessário, que representa a "substância constituidora do valor" (1867, Liv. I, p. 47), se torna não somente "força social independente e oposta aos produtores nas figuras do mercado e do dinheiro" (Gontijo, 2013, p. 14-15), mas, como capital, "em senhor dessa circulação, envolvendo-a como um momento de seu ciclo", de modo que, "[d]e 'em si', o capital se torna "para si" (idem, p. 17). Completa-se, deste modo, o processo de subjetivação (embora defectiva) ${ }^{31}$ do valor, que, de substância independente, passa a subordinar os produtores, subsumindo o trabalho vivo como um momento do seu processo sem fim, em uma totalidade em que cria seus próprios pressupostos. O valor se torna sujeito autônomo que põe suas próprias condições de existência.

Para finalizar, Marx também não faz referência ao fato de que, na exposição hegeliano-marxista, "o avançar é um retroceder ao fundamento, ao originário e verdadeiro, do qual depende o princípio com o qual se começou e através do qual em realidade é produzido" (Hegel, 1812, p. 66), de modo que se tem "um percurso circular em si mesmo, em que o Primeiro se transforma em Último e o Último se transforma em Primeiro" (idem), ou seja, se "chega afinal a um ponto que nada mais é que o seu ponto de partida: a síntese final é também a tese inicial" (Kojève, 1947, p. 440-441). De fato, a mesma "progressão em círculo [da] análise" ocorre quando se considera as "sociedades de produção capitalista desenvolvida" (Marx, 1863-1866, p. 109), pois "nelas, a mercadoria aparece tanto na qualidade de premissa (condição de existência) elementar e constante do capital, como, por outra parte, enquanto resultado imediato do processo capitalista de produção". Em outras palavras, "a mercadoria, na media em que é forma elementar e geral do produto, aparece essencialmente como o produto e o resultado do processo capitalista de produção" (idem, p. 110). O alfa ressurge por meio da mediação do ômega.

\section{Referências bibliográficas}

ALTHUSSER, L. (1967). La revolución teórica de Marx. Trad. de Marta Harnecker. Buenos Aires: Siglo Veintiuno, 1974.

(31) Veja-se Müller (1982, p. 39). 
CIRNE LIMA, C. Dialética para principiantes. Porto Alegre: EDIPUCRS, 1997.

COMBRIE, A. C. (1959). Historia de la ciencia: De San Agustín a Galileo. Madrid: Alianza Editorial, 1974. 2v.

CUNNINGHAM, G. W. Thought and reality in Hegel's system. Kitchener: Batoche Books, 1910.

DE OLIVEIRA, M. A. Dialética hoje. São Paulo: Loyola, 2004.

DE PAULA, J. A. A "introdução dos Grundrisse". In: DE PAULA, João Antônio (Org.). O ensaio geral: Marx e a crítica da economia política (1857-1858). Belo Horizonte: Autêntica, 2010. p. 89-108.

GIANNOTTI, J. A. Origens da dialética do trabalho. São Paulo: Difel, 1966.

GONTIJO, C. A dialética da transformação de valores em preços. Economia e Sociedade, v. 22, p. 1-41, abr. 2013.

. O caminhar do Logos: da matemática à ciência da sociedade. Ciência e Conhecimento, v. 3, n. 11, p. 13-103, maio 2008.

HEGEL, G. W. F. (1820). Princípios de filosofia do direito. Trad. de Orlando Vitorino. Lisboa: Martins Fontes, 1976. (1812). Ciencia de la lógica. Buenos Aires: Solar/Hachette, 1968. (1807). A fenomenologia do espírito. In: Hegel. Trad. de Wenceslao Roces com a colaboração de Ricardo Guerra. São Paulo: Abril Cultural, 1980, p. 1-75.

HÖFFE, O. (2004). Immanuel Kant. Trad. de Christian Viktor Hamm e Valério Rohden. São Paulo: Martins Fontes, 2005.

ILYENKOV, E. (1960). The dialectics of the abstract and the concrete in Marx's capital. Trad. para o inglês de Sergei Kuzyakov. New York: Progress Publishers, 1982.

KANT, I. (1787). Crítica da razão pura. Trad. de Valério Rohden e Udo Baldur Moosburger. São Paulo: Abril Cultural, 1980.

KOJÈVE, A. (1947). Introdução à leitura de Hegel. Trad. de Estela dos Santos Abreu. Rio de Janeiro: Contraponto: EDUERJ, 2002.

KOSÍK, K. (1963). Dialética do concreto. Trad. de Célia Neves e Alderico Toríbio. Rio de Janeiro: Paz e Terra, 1976.

LIMOEIRO, M. Periodização e a ciência da história - Observações preliminares. São Paulo: PUC, 1977. Mimeografado. 
LOSEE, J. Introdução histórica à filosofia da ciência. Trad. de Borisas Cimbleris. Belo Horizonte: Itatiaia, 1979.

LUKÁCS, G. (1919-1922). História e consciência de classe. Trad. de Telma Costa. Porto: Publicações Escorpião, 1974.

(1971a). Ontologia do ser social. Os princípios ontológicos fundamentais de Marx. São Paulo: Livraria Editora Ciências Humanas, 1979.

(1971b). Ontologia do ser social. A falsa e a verdadeira ontologia de Hegel. São Paulo: Livraria Editora Ciências Humanas, 1979.

MARX, K. (1867-94). O capital. Trad. de Regis Barbosa e Flávio R. Kothe. São Paulo: Abril Cultural, 1983. 4v.

(1863-1866). El Capital, Livro I, Capítulo VI (Inédito). Buenos Aires: Siglo XXI, 1974.

(1857-1858). Elementos fundamentales para la critica de la economia política (Borrador) 1857 - 1858. Buenos Aires: Siglo Veintiuno, 1971. 3v.

(1857-1858b). Formações econômicas pré-capitalistas. Rio de Janeiro: Paz e Terra, 1975.

(1857). Para a crítica da economia política. In: MANUSCRITOS econômico filosóficos e outros textos escolhidos. Tradução de José Arthur Giannotti e Edgar Malagodi. São Paulo: Abril Cultural, 1978, p. 107-257.

; ENGELS, F. (1845-46). La Ideologia Alemana. Tradução para o espanhol de Wenceslao Roces. Montevidéu: Pueblos Unidos; Barcelona: Grijalbo, 1974.

MÜLLER, M. L. Exposição e método dialético em "O Capital”. Boletim SEAF, vol. 2, p. 17-41.

MURE, G. R. G. (1950). A study of Hegel's logic. Wrdyport: Greenwood Press, 1984.

NEWTON, I. 1687. Princípios matemáticos da filosofia natural. Trad. de Carlos Lopes de Mattos e Pablo Rubén Marisconda. In: NEWTON, Leibniz (I). São Paulo: Abril Cultural, 1979. p. 1-22.

Ótica. 1704. Trad. de Pablo Rubén Marisconda. In: NEWTON, Leibniz (I). São Paulo: Abril Cultural, 1979. p. 23-57.

PAVIANI, J. Filosofia e método em Platão. Porto Alegre: EDIPUCRS, 2001.

PEREIRA, O. P. Ciência e dialética em Aristóteles. São Paulo: Unesp, 2000. 
RANIER, J. Trabalho e dialética. Hegel, Marx e a teoria social do devir. São Paulo: Boitempo, 2011.

REALE, G. (1991). Para uma nova interpretação de Platão. São Paulo: Loyola, 1997.

UCHIDA, H. Grundrisse and Hegel logic. Marx1's Grundrisse and Hegel's logic. London: Routledge, 1988. Excertos disponíveis em: http://www.marxists.org/subject/japan/uchida/ .

VAZ, H. C. de L. A dialética da história de Hegel. Belo Horizonte: UFMG, 1982. (Caderno 4). Mimeografado.

ZELENÝ, J. (1968). The logic of Marx. Totowa: Rowman and Littlefield, 1980. 